\title{
The Bishesta campaign: a menstrual hygiene management intervention for people with intellectual impairments and their carers
}

\author{
Jane Wilbur, Islay Mactaggart, Thérèse Mahon, \\ Belen Torondel, Shaffa Hameed, and Hannah Kuper
}

\begin{abstract}
This paper describes the components of the Bishesta campaign: a behaviour change intervention for menstrual hygiene management (MHM), targeting young people with intellectual impairments, and their carers in Nepal. The campaign uses two fictitious characters: Bishesta (a young person with an intellectual impairment) and Perana (her carer), and consists of three group training modules. 'Period packs', designed to make MHM behaviours attractive and easy to adopt, are given to the young people. Packs include storage bags, a bin, and stories about Bishesta menstruating and learning to manage as independently as possible, with Perana's support. Carers receive a calendar to track the young person's menstrual cycle. A Bishesta doll, with removable clothes, underwear, and a miniature 'period pack' is used in training to demonstrate MHM. Evaluation findings show the intervention is feasible at small scale, so further research on how to scale up the intervention in an evidence-based way is required.
\end{abstract}

Keywords: menstrual hygiene management, behaviour change, disability, carer, Nepal

GLOBALLY, AN ESTIMATED 800 MILLION PEOPLE menstruate every day (Sebastian et al., 2013). Many of these people face challenges managing their menstruation hygienically, especially those living in low- and middle-income countries where there is inadequate menstrual hygiene management (MHM) information, guidance, and facilities (Sommer et al., 2016; Hennegan et al., 2017, 2019). A growing body of evidence highlights that people with disabilities face additional barriers to MHM and very few interventions exist to address these (Wingfield et al., 1994; Kaskowitz et al., 2016; Márquez-González et al., 2018; Harvey et al., 2019; Dündar and Özsoy, 2020). The consequences of a lack of MHM for people with disabilities are severe and include shame, abuse, social isolation, and sterilization

Jane Wilbur (jane.wilbur@lshtm.ac.uk), Research Fellow, International Centre for Evidence in Disability, London School of Hygiene \& Tropical Medicine; Islay Mactaggart (Islay.Mactaggart@lshtm.ac.uk),

Assistant Professor, London School of Hygiene \& Tropical Medicine; Thérèse Mahon (Thérèsemahon@wateraid.org), Regional Programme Manager, South Asia, WaterAid, London; Belen Torondel (belen.torondel@lshtm.ac.uk), Assistant Professor, London School of Hygiene \& Tropical Medicine; Shaffa Hameed (Shaffa.hameed@Ishtm.ac.uk), Research Fellow, London School of Hygiene \& Tropical Medicine; Hannah Kuper (Hannah.Kuper@lshtm.ac.uk), Professor, London School of Hygiene \& Tropical Medicine

(c) The authors, 2021. This open access article is published by Practical Action Publishing. Permission must be obtained from the authors or the publisher before reuse. www.practicalactionpublishing.com, ISSN: 0262-8104/1756-3488 
(Harvey et al., 2019; Wilbur et al., 2019b, 2021; Dündar and Özsoy, 2020; Steele and Goldblatt, 2020). We therefore used evidence-based methods to design and evaluate an MHM intervention for people with disabilities. This article describes the intervention developed, its implementation, and feasibility and acceptability in the Kavre district, Nepal.

\section{Box 1 MHM definition}

'Women and adolescent girls are using a clean menstrual management material to absorb or collect menstrual blood, that can be changed in privacy as often as necessary for the duration of a menstrual period, using soap and water for washing the body as required, and having access to safe and convenient facilities to dispose of used menstrual management materials. They understand the basic facts linked to the menstrual cycle and how to manage it with dignity and without discomfort or fear' (UNICEF, 2019).

\section{The Bishesta campaign: overview}

The Bishesta campaign is an evidence-based intervention to improve understanding and behaviours around menstrual hygiene management (MHM) for people with intellectual impairments and their carers. It was designed using the Behaviour Centred Design model (Aunger and Curtis, 2016), and included: 1) systematically reviewing existing literature on disability and MHM (Wilbur et al., $2019 \mathrm{~b})$; 2) formative research to understand the behaviours and barriers to MHM faced by young people with a disability, and their carers in the Kavrepalanchok (Kavre) district, Nepal (Wilbur et al., 2021); 3) co-creating the Bishesta campaign (Wilbur et al., 2018); 4) pilot-testing; and 5) evaluating the intervention (Wilbur et al., 2019a).

\section{Informing the Bishesta campaign}

Formative research was conducted to understand behaviours and barriers to MHM for 20 people with a disability, aged 15-24 who menstruate, and 13 carers who provide menstrual support (Wilbur et al., 2021). A variety of qualitative data collection methods were applied to triangulate findings: in-depth interview, observation, PhotoVoice, and ranking. Results showed that barriers to MHM differed according to impairment group: for people with mobility, self-care and visual impairments, inaccessible WASH facilities were a significant issue. People with intellectual impairments were unable to access MHM information, or it was withheld. Many showed their menstrual blood to others and were abused by their carers and the general public as a result. Carers had no information on how to support another person's menstruation and felt isolated. Very few participants used pain relief and the majority followed menstrual restrictions. A systematic review of relevant literature revealed that there are MHM interventions for people with mobility, visual, and hearing impairments, but nothing for people with intellectual impairments and their carers in low- and middle-income countries (Wilbur et al., 2019b). Therefore, the Bishesta campaign was developed to begin to address this. 


\section{Bishesta campaign target groups, behaviours, and human motives}

The review of existing literature and formative research findings both showed that the largest gap in MHM was for people with intellectual disabilities and their carers, and so these were chosen as the campaign's target groups (see Table 1). The target behaviours of the campaign were to use a menstrual material and pain relief, not to show

Table 1 Campaign target groups, behaviours, components, and rationale

\begin{tabular}{|c|c|c|c|}
\hline \multirow{2}{*}{$\begin{array}{l}\text { Target } \\
\text { group }\end{array}$} & \multirow{2}{*}{$\begin{array}{l}\text { Target } \\
\text { behaviours }\end{array}$} & \multicolumn{2}{|c|}{ Campaign components: 'Period packs' } \\
\hline & & Item & Rationale and action \\
\hline \multirow[t]{6}{*}{$\begin{array}{l}\text { Young } \\
\text { person }\end{array}$} & \multirow[t]{3}{*}{$\begin{array}{l}\text { Use a } \\
\text { menstrual } \\
\text { material }\end{array}$} & \multirow{2}{*}{$\begin{array}{l}\text { A branded storage bag to keep } \\
\text { menstrual materials at home, } \\
\text { containing a tailor-made cloth } \\
\text { menstrual pad and a strip of } \\
\text { folded, soft cloth }\end{array}$} & $\begin{array}{l}\text { Young person always knows where } \\
\text { to get new menstrual material and } \\
\text { does not need to rely on carers. }\end{array}$ \\
\hline & & & \multirow[t]{2}{*}{$\begin{array}{l}\text { She knows where and how to } \\
\text { dispose of used menstrual material. }\end{array}$} \\
\hline & & $\begin{array}{l}\text { A small, flip-top menstrual bin } \\
\text { for disposal at home, always kept } \\
\text { next to the young person's bed }\end{array}$ & \\
\hline & $\begin{array}{l}\text { Use pain } \\
\text { relief }\end{array}$ & $\begin{array}{l}\text { A pain bangle with three } \\
\text { colours (red, orange, and } \\
\text { yellow) representing the severity } \\
\text { of menstrual discomfort }\end{array}$ & $\begin{array}{l}\text { If the young person is unable to } \\
\text { communicate verbally, she can } \\
\text { use the pain bangle to request } \\
\text { pain relief. }\end{array}$ \\
\hline & \multirow[t]{2}{*}{$\begin{array}{l}\text { Don't } \\
\text { show } \\
\text { menstrual } \\
\text { blood in } \\
\text { public }\end{array}$} & $\begin{array}{l}\text { A shoulder bag to carry } \\
\text { materials outside the home, } \\
\text { with a plastic bag to put used } \\
\text { menstrual materials }\end{array}$ & $\begin{array}{l}\text { The young person always } \\
\text { has enough clean menstrual } \\
\text { materials for use inside and } \\
\text { outside the home. }\end{array}$ \\
\hline & & $\begin{array}{l}\text { Two visual stories about Bishesta } \\
\text { menstruating and learning to } \\
\text { manage it as independently as } \\
\text { possible with Perana's support }\end{array}$ & $\begin{array}{l}\text { Participants see Bishesta and Perana } \\
\text { following the target behaviours and } \\
\text { are inspired to adopt them. }\end{array}$ \\
\hline \multirow[t]{8}{*}{ Carer } & \multirow{5}{*}{$\begin{array}{l}\text { Provide } \\
\text { enough } \\
\text { menstrual } \\
\text { materials }\end{array}$} & Storage bag & \multirow{3}{*}{$\begin{array}{l}\text { The bags are always full of new } \\
\text { menstrual materials and placed next } \\
\text { to the young person's bed. }\end{array}$} \\
\hline & & Shoulder bag & \\
\hline & & Menstrual bin & \\
\hline & & \multirow[t]{2}{*}{ Menstrual calendar } & $\begin{array}{l}\text { The menstrual bin is placed next } \\
\text { to the young person's bed and } \\
\text { emptied regularly. }\end{array}$ \\
\hline & & & $\begin{array}{l}\text { Track the young person's menstrual } \\
\text { cycle and prepare by filling the } \\
\text { menstrual bags. }\end{array}$ \\
\hline & $\begin{array}{l}\text { Provide } \\
\text { pain relief }\end{array}$ & Pain bangle & $\begin{array}{l}\text { If the young person shows that she is } \\
\text { in pain, the carer provides pain relief. }\end{array}$ \\
\hline & \multirow[t]{2}{*}{$\begin{array}{l}\text { Show } \\
\text { love and } \\
\text { emotional } \\
\text { support }\end{array}$} & Menstrual calendar & $\begin{array}{l}\text { Track changes in the young person's } \\
\text { emotions before and during } \\
\text { menstruation to understand any } \\
\text { changes in behaviour and respond } \\
\text { compassionately. }\end{array}$ \\
\hline & & Two visual stories & $\begin{array}{l}\text { Participants see Bishesta and Perana } \\
\text { using target behaviours and are } \\
\text { inspired to adopt them. }\end{array}$ \\
\hline
\end{tabular}


menstrual blood in public, and to provide enough menstrual materials, pain relief, and emotional support. Campaign components were designed to build upon human motives and trigger behaviour change by making the target behaviours easy to adopt (e.g. through provision of a menstrual storage bag and a menstrual calendar).

The campaign is based on two characters: Bishesta (meaning 'extraordinary' in Nepali), a young person who has an intellectual impairment, and her carer, Perana ('motivation'), both of whom practise the target behaviours (Figure 1). The characters and their lifestyle were designed to make the target behaviours attractive and inspire participants to behave like Bishesta and Perana.

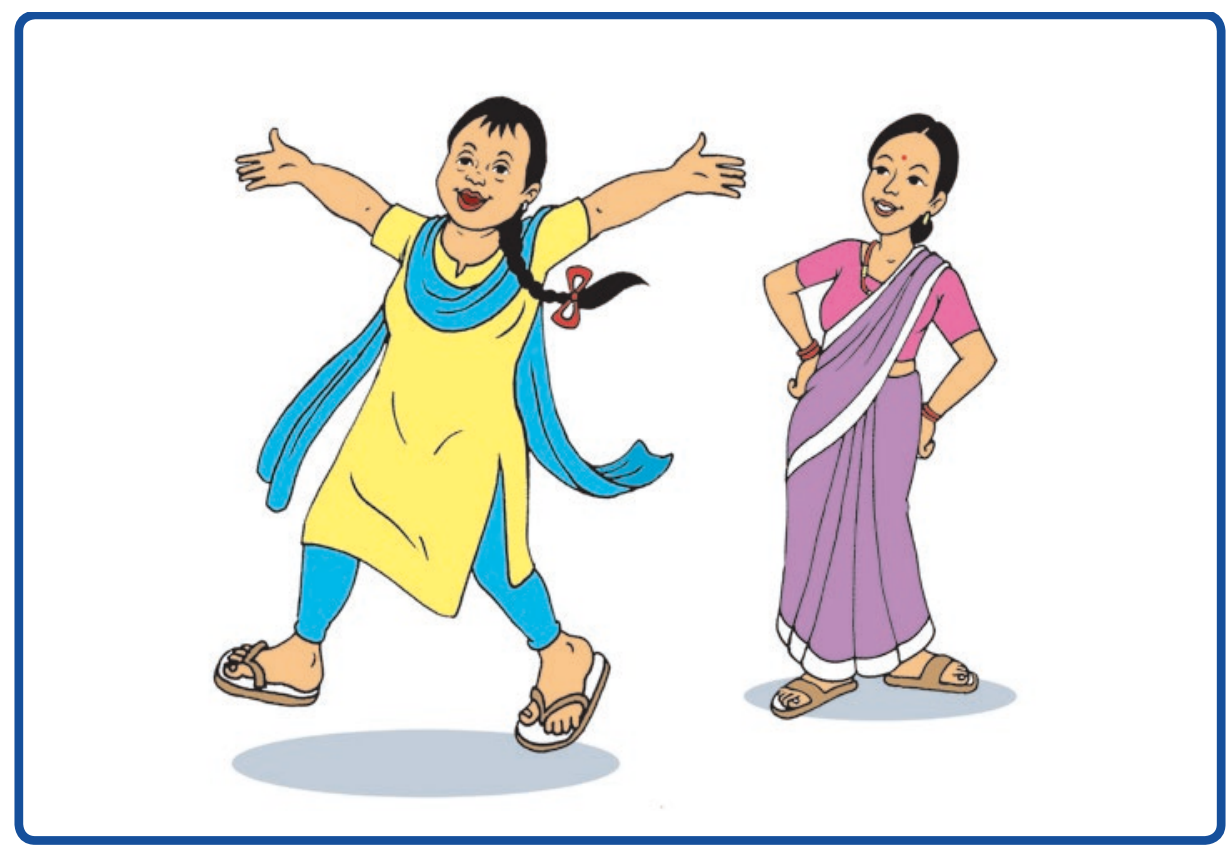

Figure 1 Bishesta and Perana

A competitive thread runs through the campaign, whereby participants strive to become 'Bishesta households' meaning they have adopted the campaign's target behaviours. Those that achieve this are awarded a certificate at the next group training. The competition is introduced in The Game of Life, during the first group training and referred to throughout.

\section{Intervention delivery}

The campaign was implemented in the Kavre district by members of the Down Syndrome Society Nepal and the Centre for Integrated Urban Development, under the supervision and guidance of JW and WaterAid Nepal. Two groups were established, each including five young people with an intellectual impairment (herewith referred to as 'young people') and their carers, who were family members and 
professionals. The groups met for three training sessions, lasting 2-3 hours each, to learn about MHM through participatory methods. The facilitation team followed a campaign manual which guided intervention delivery, and used flash cards during the sessions. The lead facilitator had a 'buddy' who observed and supported her to ensure all aspects of the session were covered.

We wanted participants to feel a sense of excitement upon arrival, so training venues were decorated with a branded campaign banner with the target behaviours on it (Photo 1), and yellow and blue flags (Photo 2).

It was important that young people felt comfortable, so the venue had a quiet space that they could withdraw to at any time. During training sessions, carers were encouraged to interact with each other to develop a support network, and help young people to feel confident and valued. To encourage the latter, a campaign ritual was carried out at the start of each group training: all participants stood in a circle, with carers facing the young person. Carers were asked to show the young person love (e.g. smiling, embracing); each introduced the other person to the group (if able and willing) and told the group something they love or appreciate about them.

Participants were asked to use positive and accurate language when talking about menstruation, instead of euphemisms that encourage taboos (Wilson et al., 2018; Hennegan et al., 2019). To ensure all information was accessible, any instructions given during the training were explained verbally, visually, and through role play. For instance, whenever key behaviours and hand washing were mentioned, visuals of these were referred to (see Supplementary material 1). Information was also repeated regularly throughout the intervention delivery to reinforce the young person's learning.

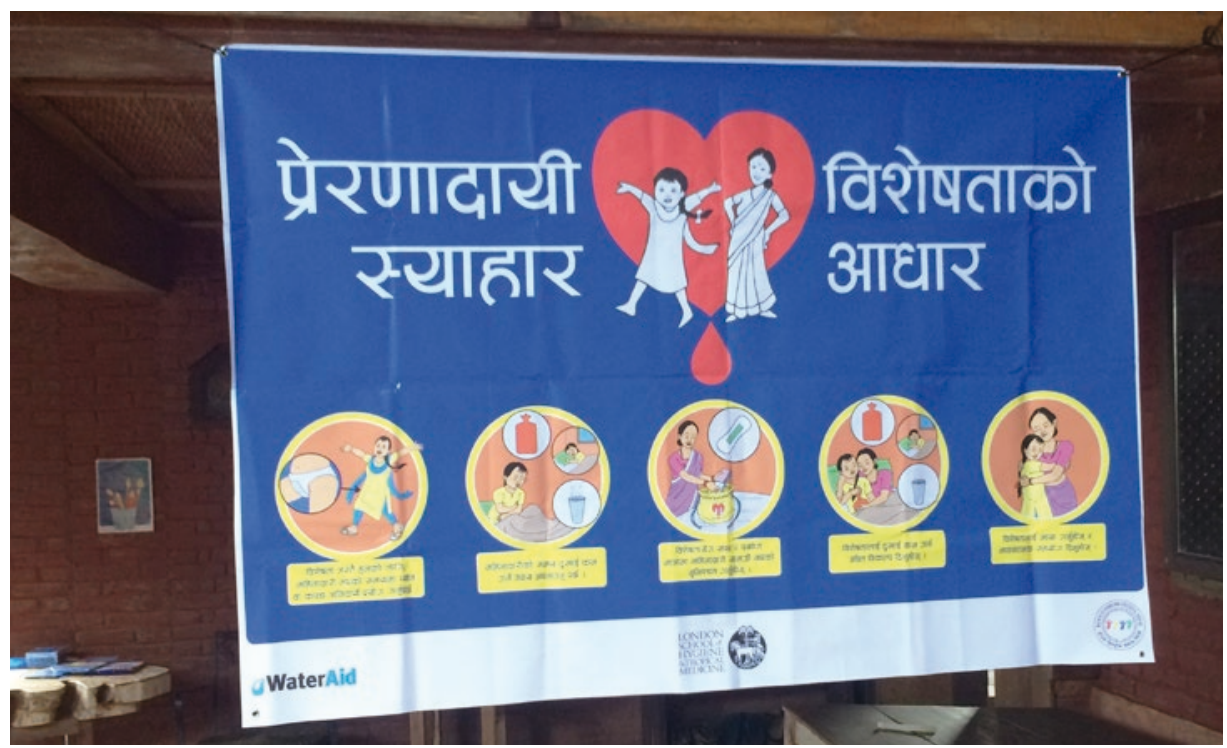

Photo 1 Campaign banner 


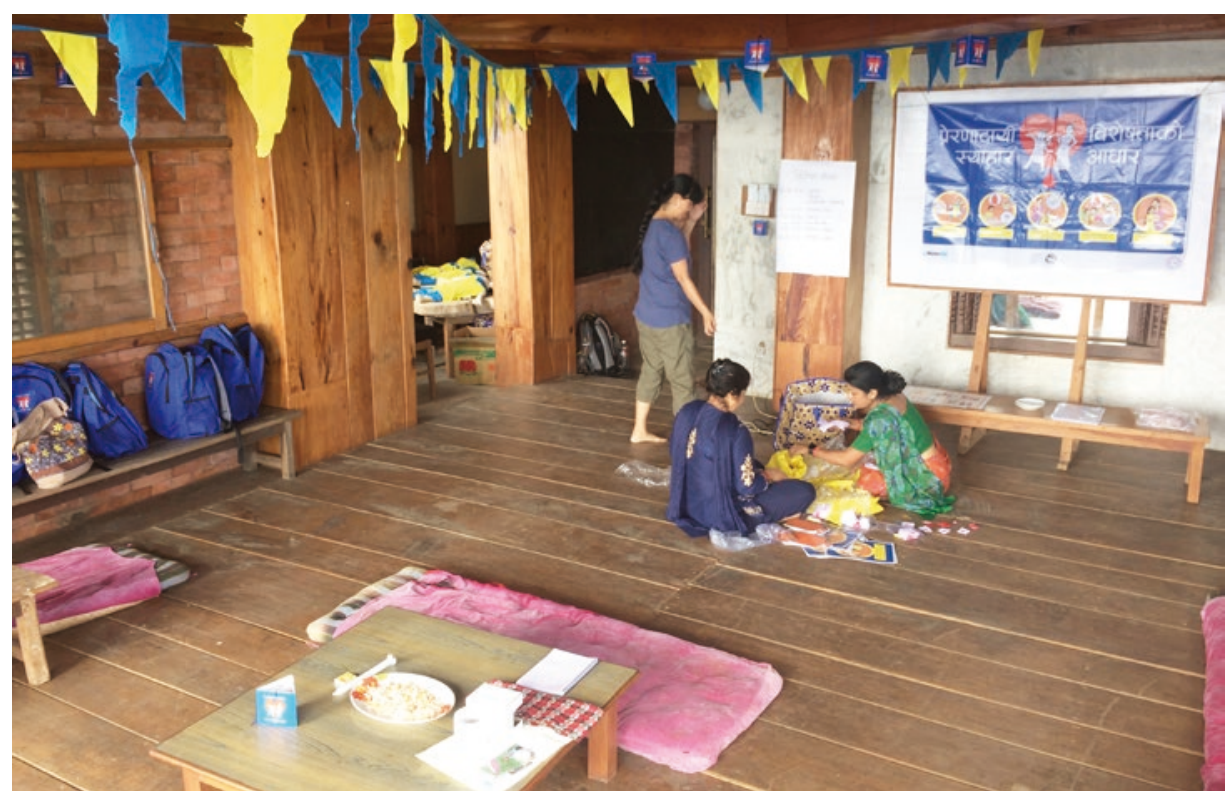

Photo 2 Yellow and blue flags

\section{Campaign components}

'Period packs' were distributed to the young people, and a menstrual calendar was given to carers (see Table 1, Figure 2, and Photos 3-5). A branded mirror was handed out to be put near the young person's bed to remind them of the target behaviours (Photo 6).

A large Bishesta doll, with removable clothes, underwear, and miniature contents of the 'period packs' were used in the group sessions to facilitate communication about, and knowledge of MHM. A smaller version of the doll was offered to the young person to take home, so that they could practise changing and disposing of Bishesta's menstrual material when they were not menstruating (Photos 7 and 8).

\section{Group training modules}

The first group training introduced the Bishesta campaign, the journey to behaviour change and the large Bishesta doll. The campaign materials were distributed, including the menstrual storage bag, menstrual bin, campaign mirror, and small Bishesta doll. The second training reinforced the target behaviours, introduced the menstrual calendar and shoulder bag, and practised their use, and announced any 'Bishesta households'. The final session introduced the visual stories, explained how they should be used, and handed out campaign certificates to all participants. Table 2 presents the content, purpose, key messages, target behaviours, and human motives of each group training. 


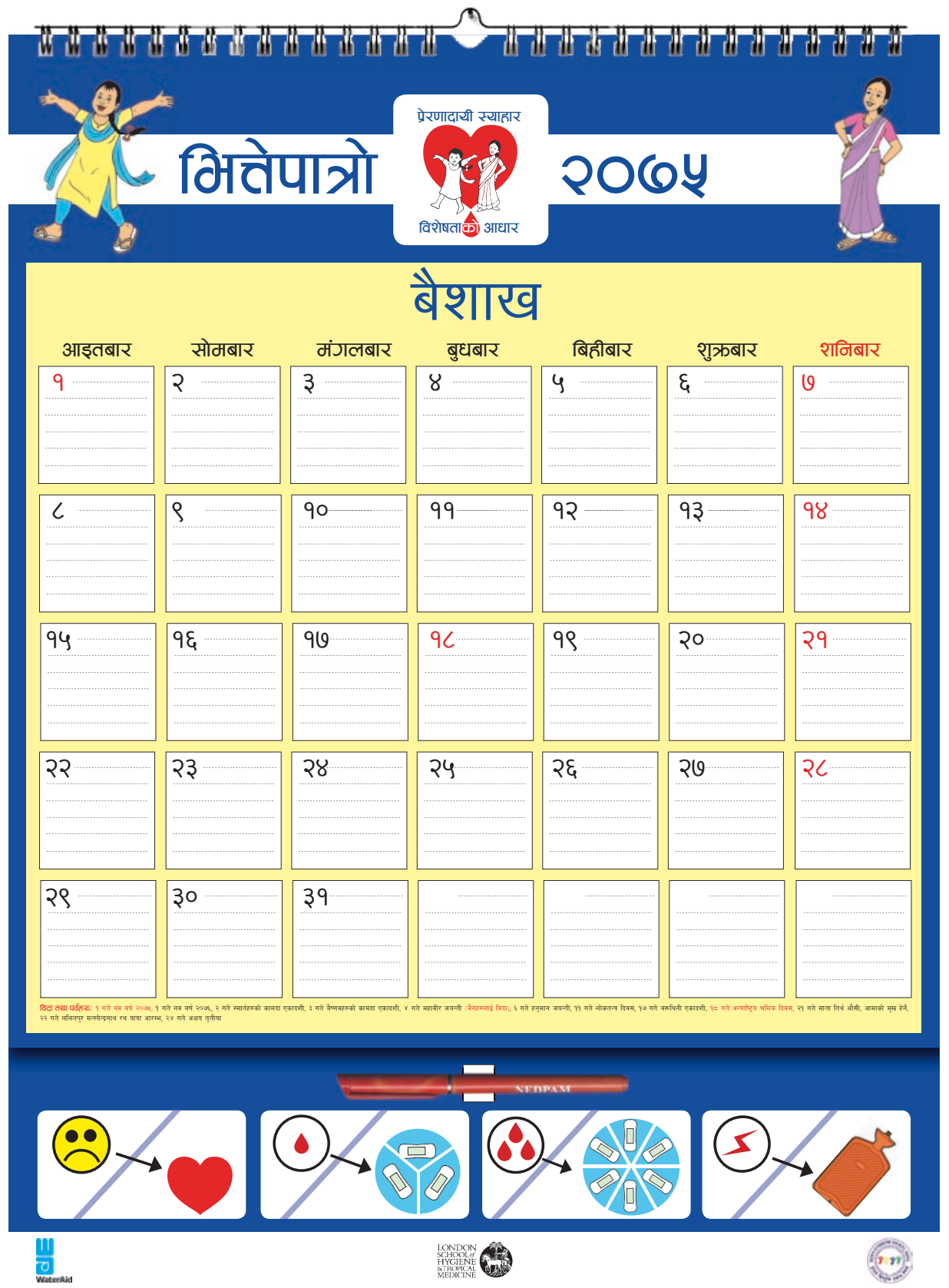

Figure 2 Menstrual calendar 


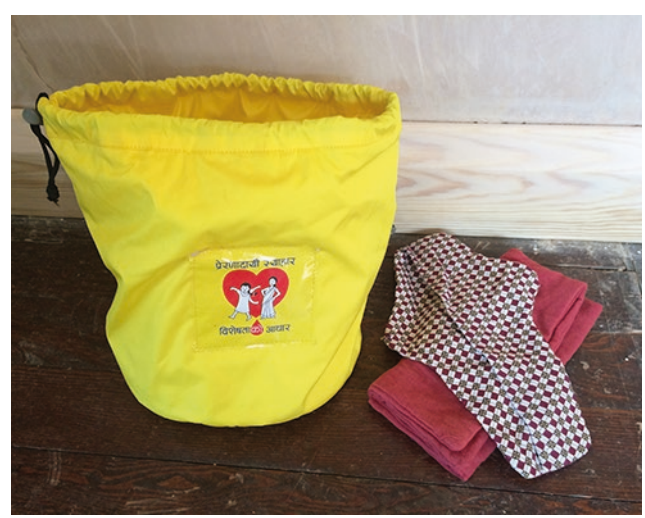

Photo 3 Period pack: menstrual material storage bag

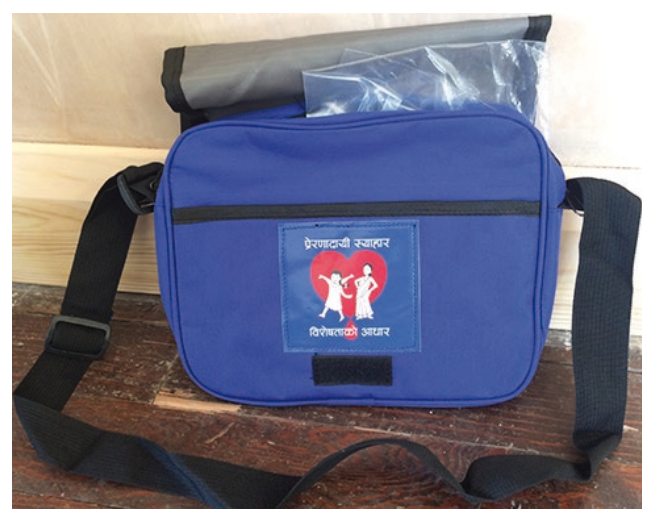

Photo 5 Period pack: menstrual shoulder bag

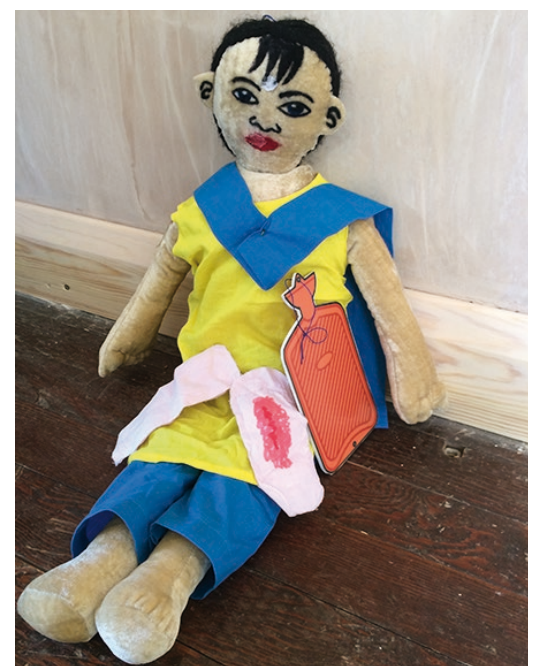

Photo 7 Large Bishesta doll

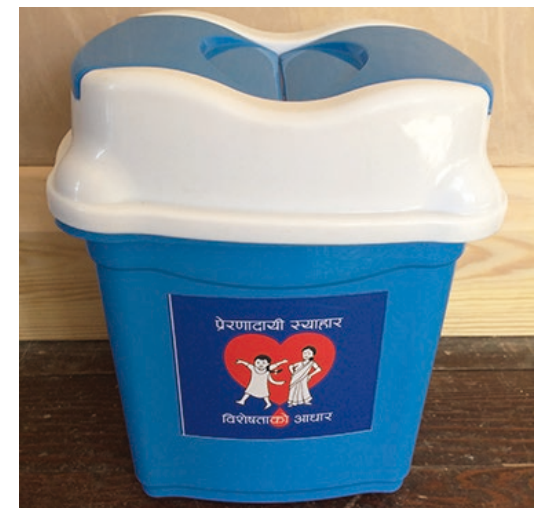

Photo 4 Period pack: menstrual bin

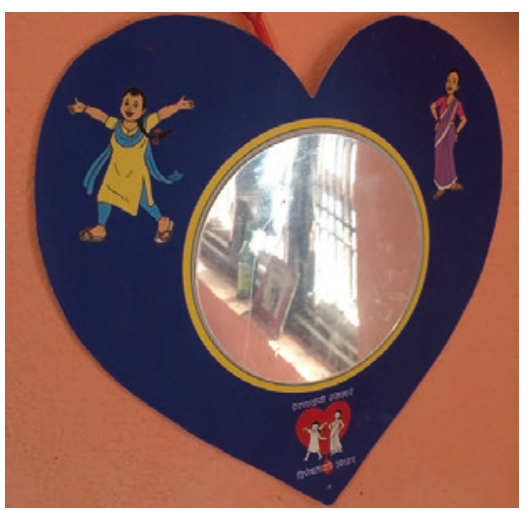

Photo 6 Branded mirror

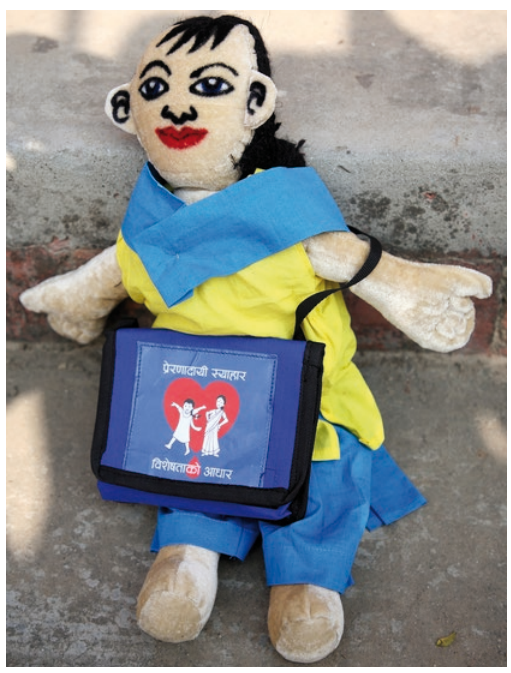

Photo 8 Small Bishesta doll 
Table 2 Outline of group training modules

\begin{tabular}{|c|c|c|}
\hline \multicolumn{3}{|l|}{ Group training 1} \\
\hline Session and method & Purpose & Key messages \\
\hline $\begin{array}{l}\text { 1. Introduction } \\
\text { (plenary } \\
\text { discussion) }\end{array}$ & $\begin{array}{l}\text { - Everyone introduces themselves } \\
\text { - Agenda shared } \\
\text { - Agree how group works together } \\
\text { - Conduct campaign ritual }\end{array}$ & $\begin{array}{l}\text { - We can all learn from each other } \\
\text { - The workshop is a supportive } \\
\text { space where people can talk } \\
\text { about menstruation } \\
\text { - A good carer shows the young } \\
\text { person love. A good carer } \\
\text { supports her to manage her } \\
\text { menstruation }\end{array}$ \\
\hline $\begin{array}{l}\text { 2. The Game of Life } \\
\text { (activity, plenary } \\
\text { discussion) }\end{array}$ & $\begin{array}{l}\text { - Help carers understand the } \\
\text { importance of helping the young } \\
\text { person manage her menstruation } \\
\text { as independently as possible } \\
\text { - Introduce the Bishesta campaign, } \\
\text { behaviours, and the Bishesta } \\
\text { household competition }\end{array}$ & $\begin{array}{l}\text { - You can be a Bishesta household } \\
\text { - Supporting a young person to } \\
\text { manage her menstruation more } \\
\text { independently, providing pain } \\
\text { relief and emotional support can } \\
\text { make her more comfortable and } \\
\text { confident }\end{array}$ \\
\hline $\begin{array}{l}\text { 3. The Bishesta Doll } \\
\text { (group work) }\end{array}$ & $\begin{array}{l}\text { - Introduce the Bishesta doll, } \\
\text { menstrual storage bag, shoulder } \\
\text { bag, and menstrual bin } \\
\text { Helps young person: } \\
\text { - know when to change a pad } \\
\text { - practise changing a pad and } \\
\text { re-dressing Bishesta } \\
\text { - understand where a person feels } \\
\text { menstrual discomfort } \\
\text { - understand that menstrual } \\
\text { symptoms can make you feel sad, } \\
\text { - angry, tired } \\
\text { - understand that pain relief may help } \\
\text { - } \text { welps carers understand: } \\
\text { - when to give pain relief }\end{array}$ & $\begin{array}{l}\text { - Young person can manage } \\
\text { their own menstruation more } \\
\text { independently if supported } \\
\text { - Young person can feel more } \\
\text { comfortable and confident } \\
\text { at home and in public when } \\
\text { menstruating, if carers and young } \\
\text { people follow key behaviours }\end{array}$ \\
\hline $\begin{array}{l}\text { 4. Close the } \\
\text { session (plenary } \\
\text { discussion) }\end{array}$ & $\begin{array}{l}\text { - Remind participants of topics } \\
\text { covered } \\
\text { - Encourage a sense of competition } \\
\text { - Explain household monitoring visits } \\
\text { - Share next training session date; } \\
\text { encourage people to attend } \\
\text { - Thank attendees for participating }\end{array}$ & $\begin{array}{l}\text { - We can all be Bishesta households } \\
\text { - Attending the next training } \\
\text { session is important }\end{array}$ \\
\hline Group training 2 & & \\
\hline Session and method & Purpose & Key messages \\
\hline $\begin{array}{l}\text { 1. Introduction } \\
\text { (plenary } \\
\text { discussion) }\end{array}$ & $\begin{array}{l}\text { - Facilitators and participants greet } \\
\text { each other } \\
\text { - Agenda shared }\end{array}$ & $\begin{array}{l}\text { - See 'Introduction' in Group } \\
\text { training } 1\end{array}$ \\
\hline
\end{tabular}


Table 2 Continued

\begin{tabular}{|c|c|c|}
\hline \multicolumn{3}{|l|}{ Group training 1} \\
\hline Session and method & Purpose & Key messages \\
\hline & $\begin{array}{l}\text { - Remind the group how to work } \\
\text { together } \\
\text { - Carry out campaign ritual }\end{array}$ & \\
\hline $\begin{array}{l}\text { 2. Menstrual } \\
\text { shoulder bag } \\
\text { (group work) }\end{array}$ & $\begin{array}{l}\text { - Introduce the menstrual shoulder } \\
\text { bag and how to use it } \\
\text { - Young person - practise changing } \\
\text { Bishesta's menstrual pad } \\
\text { - Carers - understand the } \\
\text { importance of keeping the } \\
\text { shoulder bag full and in the } \\
\text { same place }\end{array}$ & $\begin{array}{l}\text { - Change your pad } \\
\text { - Get clean menstrual pads out } \\
\text { of the menstrual storage bag or } \\
\text { shoulder bag } \\
\text { - Always take the shoulder bag } \\
\text { out with you when you're } \\
\text { menstruating } \\
\text { - Carers ensure bags are always full } \\
\text { and in the same place }\end{array}$ \\
\hline $\begin{array}{l}\text { 3. Menstrual } \\
\text { calendar } \\
\text { (group work) }\end{array}$ & $\begin{array}{l}\text { - Introduce the menstrual calendar } \\
\text { and how to use it } \\
\text { - Handout menstrual calendars }\end{array}$ & $\begin{array}{l}\text { - Tracking the young person's } \\
\text { menstrual cycle helps carers } \\
\text { prepare for her menstruation } \\
\text { - Carers can help the young person } \\
\text { feel more comfortable and } \\
\text { confident when menstruating. } \\
\text { Young person will show you love } \\
\text { when you do this }\end{array}$ \\
\hline $\begin{array}{l}\text { 4. Close the } \\
\text { session (plenary } \\
\text { discussion) }\end{array}$ & $\begin{array}{l}\text { - Remind participants of training } \\
\text { - Encontent and target behaviours } \\
\text { competition } \\
\text { - Hand out shoulder bags } \\
\text { - Remind about the household } \\
\text { - Shonitoring visits } \\
\text { - } \text { encourage attendance } \\
\text { - Thank people for their active } \\
\text { participation }\end{array}$ & - We can all be Bishesta households \\
\hline
\end{tabular}

Group training 3

\begin{tabular}{|c|c|c|}
\hline Session and method & Purpose & Key messages \\
\hline $\begin{array}{l}\text { 1. Introduction } \\
\text { (plenary } \\
\text { discussion) }\end{array}$ & $\begin{array}{l}\text { - See 'Introduction' in Group } \\
\text { training } 2\end{array}$ & $\begin{array}{l}\text { - See 'Introduction' in Group } \\
\text { training } 1\end{array}$ \\
\hline $\begin{array}{l}\text { 2. I Change My Pad } \\
\text { visual story } \\
\text { (group work) } \\
\text { 3. I Manage } \\
\text { visual story } \\
\text { (group work) }\end{array}$ & $\begin{array}{l}\text { - Introduce visual stories and how } \\
\text { to use them } \\
\text { - Young person tells the story to } \\
\text { the carer } \\
\text { - Discuss menstruation openly } \\
\text { - Handout I Change My Pad and } \\
\text { I Manage visual stories }\end{array}$ & $\begin{array}{l}\text { - All young people can lead a } \\
\text { dignified life when they are } \\
\text { menstruating } \\
\text { - Menstrual blood is not shameful. } \\
\text { Sometimes menstrual blood leaks } \\
\text { on your clothes. People should } \\
\text { not be scolded for this }\end{array}$ \\
\hline
\end{tabular}

(Continued) 
Table 2 Continued

\begin{tabular}{lll}
\hline Group training 1 & & \\
\hline Session and method & Purpose & Key messages \\
\hline & & $\begin{array}{l}\text { Menstrual materials absorb blood } \\
\text { and can prevent clothes staining. } \\
\text { Materials need to be clean, soft, } \\
\text { absorbent and stay in place } \\
\text { without rubbing. They need to be } \\
\text { clean and comfortable, they must } \\
\text { be washed and dried thoroughly } \\
\text { after use }\end{array}$ \\
$\begin{array}{ll}\text { 4. Certificate and } \\
\text { close (plenary } \\
\text { discussion) }\end{array}$ & $\begin{array}{l}\text { Content, target behaviours, 'period } \\
\text { packs' and what they are for }\end{array}$ & \\
& $\begin{array}{l}\text { Thank participants for their active all Bishesta households! } \\
\text { participation }\end{array}$ & \\
& - Congratulate people for \\
completing the Bishesta campaign & \\
& - Hand out certificates & \\
\hline
\end{tabular}

\section{Group training 1}

The Game of Life (a participatory way to convey a message; Coe and Wapling, 2015) was conducted to introduce Bishesta and Perana, the key behaviours and benefits of adopting them, as well as the 'Bishesta household' competition.

Four volunteers were asked to stand in a line representing two households: one with Bishesta and Perana, and the other with a Nepali carer and a Nepali young person who has an intellectual impairment. Each volunteer wore a mask with the character's face on it. The facilitator explained that three scenarios would be read out, and the volunteers must take two steps forward if they considered it to be a very positive experience, one step forward for a somewhat positive experience, one step back if they considered it a less positive experience and two steps back for a very negative experience. These verbal instructions were also explained visually (Figure 3).

The facilitator ran through the following three scenarios: 1) when the young person menstruates for the first time; 2) when the young person has menstrual cramps, is upset, refusing to eat, and is withdrawn; and 3) when the carer needs to leave the young person at home alone when she is menstruating. After each scenario was read out, the volunteers took their steps and then the group discussed why.

In the Bishesta household, Perana explains about menstruation and how to manage it, she comforts Bishesta when she is upset and gives her pain relief (e.g. a hot water bottle for her stomach), which Bishesta uses. Perana reminds Bishesta how to change her menstrual material and shows her where to get a new one. When she leaves the home, Bishesta feels comfortable and confident. In the second household, the carer does not provide this support, she follows menstrual restrictions (such as sleeping separately from others, not worshipping, entering the kitchen, not touching food or plants because menstrual blood is believed to be dirty 


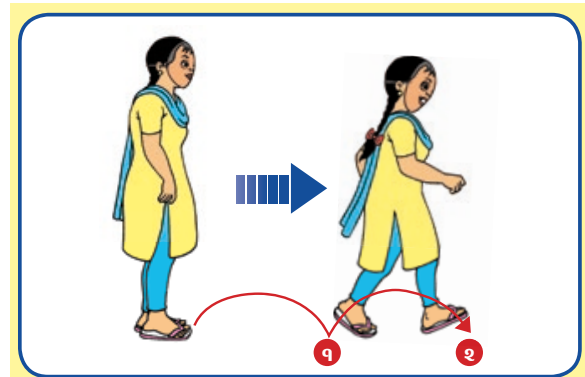

1. Two steps forward in response to a very positive experiences

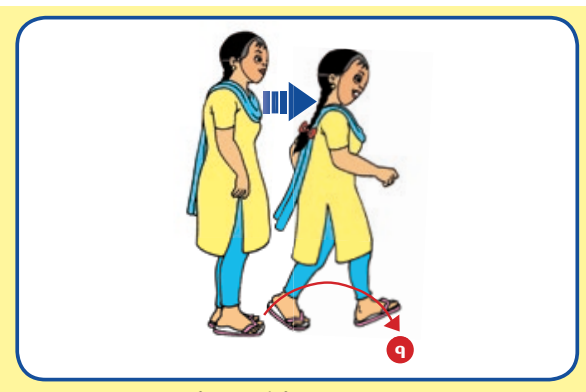

2. One step forward for a positive experience

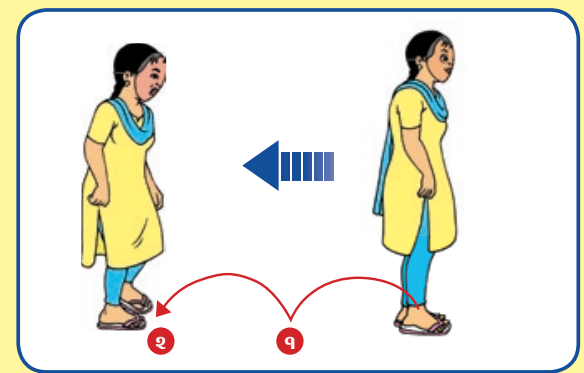

4. Two steps back for a negative experience
3. One step back for a less positive experience

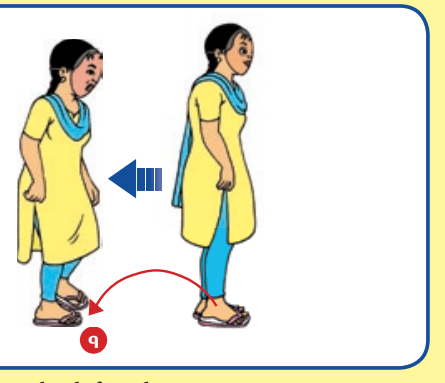

Figure 3 Visual instructions for The Game of Life

and contaminating); does not understand why her daughter is upset and gets angry with her. She puts an uncomfortable, thick, folded menstrual material in the young person's underwear, does not show her where she can get a new one, and leaves home for the day to work. The young person takes the menstrual material off and goes out in the community with menstrual blood on her clothes. People she meets are surprised and shun her; her family is embarrassed and scold her. At the end of the session, the participants are asked which household they want to personify, and they enter a competition to become 'Bishesta households'.

During the Bishesta Doll session, facilitators worked with up to two young people and their carers, and introduced the large doll. The young person was asked, or supported, to take a used menstrual material out of the doll's underwear, dispose of the used material in the menstrual bin, and wash her hands. Next, to get an unused menstrual material from the menstrual storage bag, place it in the doll's underwear and dress her. Whenever key behaviours were enacted, the facilitator responded positively and held up the relevant card to positively reinforce the target behaviour (see Supplementary material 1).

The facilitator demonstrated that the doll was experiencing menstrual discomfort, by putting a sad expression on her face and doubling her over while the doll held her stomach. The young person was then asked what she thought was wrong with Bishesta. The facilitator put a pain symbol on areas of the body (breasts, back, head, stomach) where pain may be experienced and asked the young person if, and where she has felt menstrual discomfort. Carers were asked what they could do to help 
Bishesta, such as giving her a hot water bottle, reassuring her, encouraging her to rest. Once pain relief or comfort was provided, the facilitator took the pain symbol off and put a happy expression on the doll.

\section{Group training 2}

During the second group training session, young people were reminded of the content of the first session using the Bishesta doll. The facilitator showed the menstrual shoulder bag and contents to the participants, then enacted the doll leaving home without it. In this role play, Perana called Bishesta back and gave her the bag with a new menstrual material and plastic bag in it. While out, Bishesta needed to change her menstrual material and the young person was encouraged to do that; putting the used material in the plastic bag inside the shoulder bag, taking it home, and disposing of it in the menstrual bin before washing her hands. Menstrual calendars were given out to carers and their purpose explained, before the group revisited key behaviours.

\section{Group training 3}

The visual stories were presented which show Bishesta menstruating for the first time and Perana supporting her to manage as independently as possible. They are intended to improve communication on MHM and reinforce the target behaviours (see Supplementary material 2).

Looking at the visual stories should be an enjoyable and empowering experience for the young person. To encourage this, role play was used to explain how carers can facilitate this. Carers worked in pairs: one was the young person, the other was the carer. Firstly, the carer held the books and did not let the young person touch it; the carer turned the pages and told the young person what was happening in each scene. In plenary, pairs reflected on how that made them feel (e.g. frustrated, disempowered, disinterested). In the second role play, the young person held the book; the carer asked what she thought was happening on each page, and encouraged the young person when she responded, correcting information if required. The young person turned the page when she was ready and continued to interpret the story herself. In plenary the group discussed how the carer helped the young person feel confident, respected, and empowered through the process. Carers then introduced the visual stories to the young person they support and facilitators walked around reminding carers of the process, if required.

In the final session, the facilitator congratulated all participants for becoming Bishesta households and handed out campaign certificates.

\section{Acceptability and feasibility of the intervention}

The Bishesta campaign was evaluated in 2019. Data was collected through interviewing carers, facilitators, and WaterAid staff, observing the young people, and gathering process monitoring data. Results showed that the intervention was acceptable and feasible for the target groups and facilitators; most of the 'period pack' content 
was used, improvements were recorded across all target behaviours and there were indications that young people's levels of comfort, self-confidence, and independence had increased during menstruation (Wilbur et al., 2019a). Recommended amendments to the campaign included: 1) making minor changes to the intervention, such as simplifying the menstrual calendar as it was difficult for participants to understand and use; and 2) integrating the campaign into disability service providers' existing self-care programmes aimed at supporting people with intellectual impairments to live as independently as possible.

The Bishesta campaign is free to download (see WaterAid, 2020). However, to date it has been piloted at a small scale in Nepal, and potentially needs modifying for different settings (WaterAid, 2020). This adaptation would include conducting formative research to understand if the target behaviours are relevant, and revising the visuals, names of the characters, and potentially delivery mechanisms to ensure relevance to the new context.

The London School of Hygiene \& Tropical Medicine and World Vision received funding from Elrha's Humanitarian Innovation Fund to adapt and pilot the campaign in humanitarian settings in Vanuatu and a refugee camp in a second country (to be confirmed) (Elrha, 2020). This includes developing the capacity of local researchers (including people with disabilities) to conduct formative research to assess the need for and feasibility of the campaign. Visuals, characters' names, and implementation mechanisms will be adapted so that the campaign is culturally relevant and potentially suitable for the humanitarian setting. It will be delivered and evaluated to understand its feasibility and acceptability.

Further evidence is required to support scale up of the campaign, ensuring that it continues to be acceptable and feasible in other settings beyond Kavre. Recommendations for this are to evaluate the intervention's impact on behaviour change in Nepal. This would involve conducting a mixed methods baseline across 100 people with an intellectual impairment, implementing the Bishesta campaign with that group and their carers, gathering process monitoring data and conducting a process and impact evaluation to assess if behaviour change is sustained. If findings are positive, the intervention could be scaled up in the Central Development Region of Nepal, which includes the Kavre district.

\section{Conclusion}

The Bishesta campaign is the first MHM behaviour change intervention for people with intellectual impairments and their carers in Nepal. It has been shown to be acceptable and feasible at small scale, so further research is required to evaluate the impact of the intervention on changing behaviours among participants before it can be scaled up within Nepal.

\section{Acknowledgements}

The authors would like to thank the young people and carers who participated in the Bishesta campaign in the Kavre district. We also thank our wonderful facilitation team: Shila Thapa (lead facilitator), Pramila Dewan, Pramila Humigain, 
Dhana Kumari Sunar, and Rumani Pyakurel; Sandhya Chaulagain for coordinating the delivery and Tripti Rai for her ongoing support of the campaign.

\section{Ethics approval}

Ethical approval was received at each stage of this study. Approval for the formative research was granted by from the Research Ethics Committee at the LSHTM (reference: 12091) and the Nepal Health Research Council (reference: 102/2017). Ethical approval for the delivery of the intervention and the feasibility study was given by the Nepal Health Research Council (code 39-2018) and the LSHTM Ethics Board (code 15703).

\section{Funding}

This study was funded by the Bill \& Melinda Gates Foundation, Global Development Grant number OPP1159651, Global and Country-Level WSH Advocacy. It was also supported by Elrha, the Humanitarian Innovation Fund, Netherlands Ministry of Foreign Affairs and the UK Foreign, Commonwealth and Development Office, grant number 45437.

\section{References}

Aunger, R. and Curtis, V. (2016) 'Behaviour centred design: towards an applied science of behaviour change', Health Psychology Review 10(4): 425-46 <https://doi.org/10.1080/17437199. 2016.1219673>.

Coe, S. and Wapling, L. (2015) Training Activity 4: Game of Life [online], World Vision <https:// assets.worldvision.org.uk/files/8413/8053/8773/Training_Activity_4_game_of_life.pdf> [accessed 15 April 2021].

Dündar, T. and Özsoy, S. (2020) 'Menstrual hygiene management among visually impaired women', British Journal of Visual Impairment 38: 347-62 <https://doi.org/10.117/0264619620911441>.

Elrha (2020) 'MHM for people with intellectual impairments in emergencies' [online] <https:// www.elrha.org/project/mhm-for-people-with-intellectual-impairment-in-emergencies/> [accessed 09 December 2020].

Harvey, K., Mano, P., Lakshminarayana, I. and Gupta, S. (2019) 'G480(P) Menstruation matters: the impact of menstruation on girls and young women with severe learning difficulties and their families', Archives of Disease in Childhood 104: A193 <https://doi.org/10.1136/ archdischild-2019-rcpch.464>.

Hennegan, J., Torondel, B., Phillips-Howard, P.A., Sommer, M. and Montgomery, P. (2017) 'Time to talk about menstruation: a response', Lancet 390: 845-6 <https://doi.org/10.1016/ s0140-6736(17)31950-5>.

Hennegan, J., Shannon, A.K., Rubli, J., Schwab, K.J. and Melendez-Torres, G.J. (2019) ‘Women's and girls' experiences of menstruation in low- and middle-income countries: a systematic review and qualitative metasynthesis', PLOS Medicine 16: e1002803 <https://doi.org/10.1371/ journal.pmed.1002803>.

Kaskowitz, A.P., Dendrinos, M., Murray, P.J., Quint, E.H. and Ernst, S. (2016) 'The effect of menstrual issues on young women with Angelman syndrome', Journal of Pediatric and Adolescent Gynecology 29: 348-52 <https://doi.org/10.1016/j.jpag.2015.12.004>. 
Márquez-González, H., Valdez-Martinez, E. and Bedolla, M. (2018) 'Hysterectomy for the management of menstrual hygiene in women with intellectual disability: a systematic review focusing on standards and ethical considerations for developing countries', Frontiers in Public Health $6<$ https://doi.org/10.3389/fpubh.2018.00338>.

Sebastian, A., Hoffmann, V. and Adelman, S. (2013) 'Menstrual management in low-income countries: needs and trends', Waterlines 32: 135-53 <https://doi.org/10.3362/1756-3488.2013.015>.

Sommer, M., Caruso, B.A., Sahin, M., Calderon, T., Cavill, S., Mahon, T. and Phillips-Howard, P.A. (2016) 'A time for global action: addressing girls' menstrual hygiene management needs in schools', PLOS Medicine 13: e1001962 <https://doi.org/10.1371/journal.pmed.1001962>.

Steele, L. and Goldblatt, B. (2020) 'The human rights of women and girls with disabilities: sterilization and other coercive responses to menstruation', in Bobel, C., Winkler, I.T., Fahs, B., Hasson, K.A., Kissling, E.A. and Roberts, T.-A. (eds), The Palgrave Handbook of Critical Menstruation Studies, pp. 77-91 [online], Singapore: Springer Singapore <https://doi.org/10.1007/978-98115-0614-7_8> [accessed 15 April 2021].

UNICEF (2019) Guidance on Menstrual Health and Hygiene [online] <https://www.unicef.org/ documents/guidance-menstrual-health-and-hygiene> [accessed 15 April 2021].

WaterAid (2020) 'The Bishesta campaign: menstrual health and hygiene for people with intellectual impairments' [online], WASH Matters <https://washmatters.wateraid.org/publications/ bishesta-campaign-menstrual-health-hygiene> [accessed 15 April 2021].

Wilbur, J., Bright, T., Mahon, T., Hameed, S., Torondel, B., Mulwafu, W., Kuper, H. and Polack, S. (2018) 'Developing behaviour change interventions for improving access to health and hygiene for people with disabilities: two case studies from Nepal and Malawi', International Journal of Environmental Research and Public Health 15: 2746 <https://doi.org/10.3390/ijerph15122746>.

Wilbur, J., Mahon, T., Torondel, B., Hameed, S. and Kuper, H. (2019a) 'Feasibility study of a menstrual hygiene management intervention for people with intellectual impairments and their carers in Nepal', International Journal of Environmental Research and Public Health 16: 3750 $<$ https://doi.org/10.3390/ijerph16193750>.

Wilbur, J., Torondel, B., Hameed, S., Mahon, T. and Kuper, H. (2019b) 'Systematic review of menstrual hygiene management requirements, its barriers and strategies for disabled people', PLOS ONE 14: e0210974 <https://doi.org/10.1371/journal.pone.0210974>.

Wilbur, J., Kayastha, S., Mahon, T., Torondel, B., Hameed, S., Sigdel, A., Gyawali, A. and Kuper, H. (2021) 'Qualitative study exploring the barriers to menstrual hygiene management faced by adolescents and young people with a disability, and their carers in the Kavrepalanchok district, Nepal', BMC Public Health 21: 476 <https://doi.org/10.1186/s12889-021-10439-y>.

Wilson, E., Haver, J., Torondel, B., Rubli, J. and Caruso, B.A. (2018) 'Dismantling menstrual taboos to overcome gender inequality', The Lancet Child \& Adolescent Health 2: e17 <https://doi. org/10.1016/S2352-4642(18)30209-8>.

Wingfield, M., Healy, D.L. and Nicholson, A. (1994) 'Gynaecological care for women with intellectual disability', Medical Journal of Australia 160: 536-8 [online] <https://europepmc.org/ article/med/8164550> [accessed 15 April 2021]. 


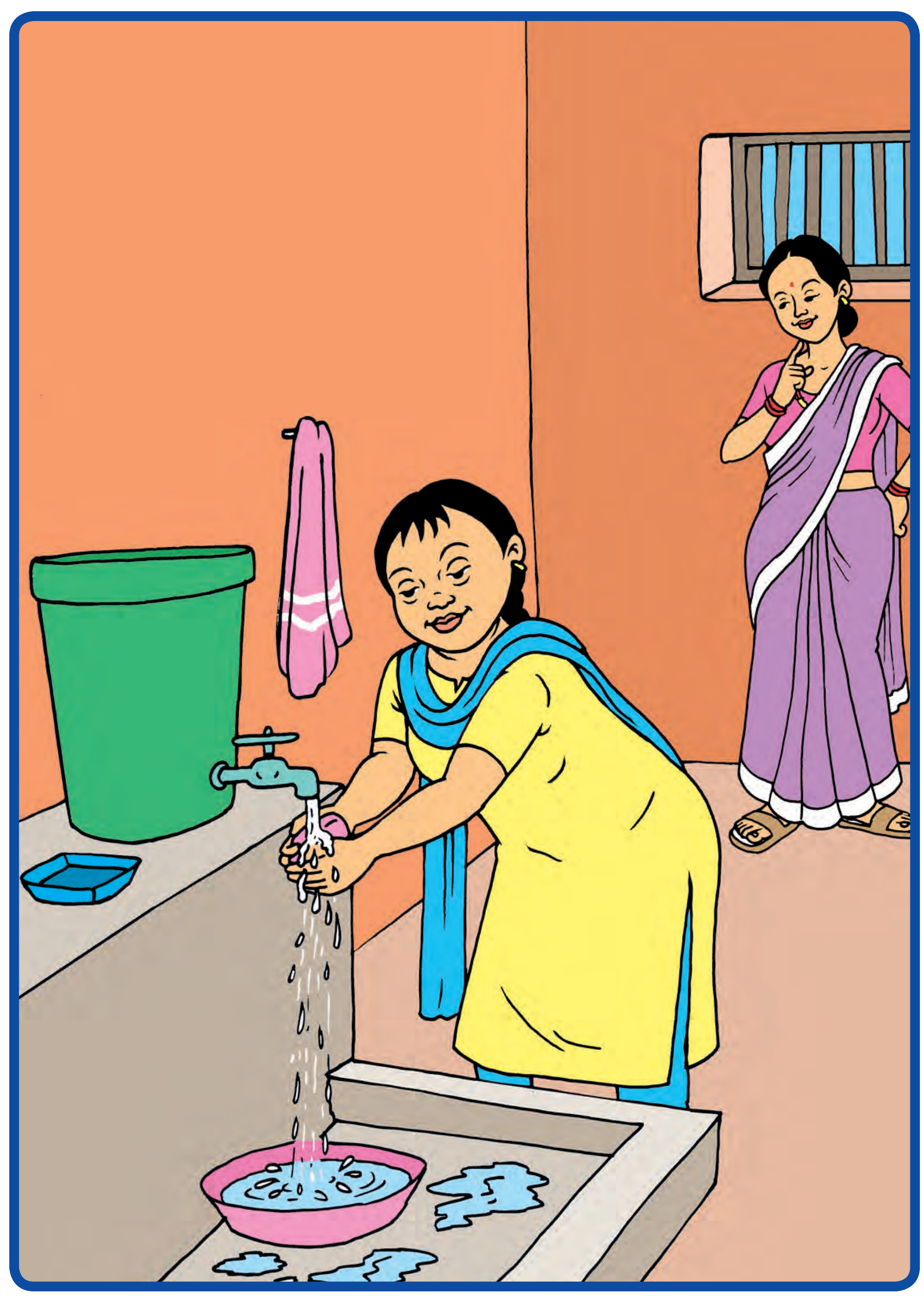




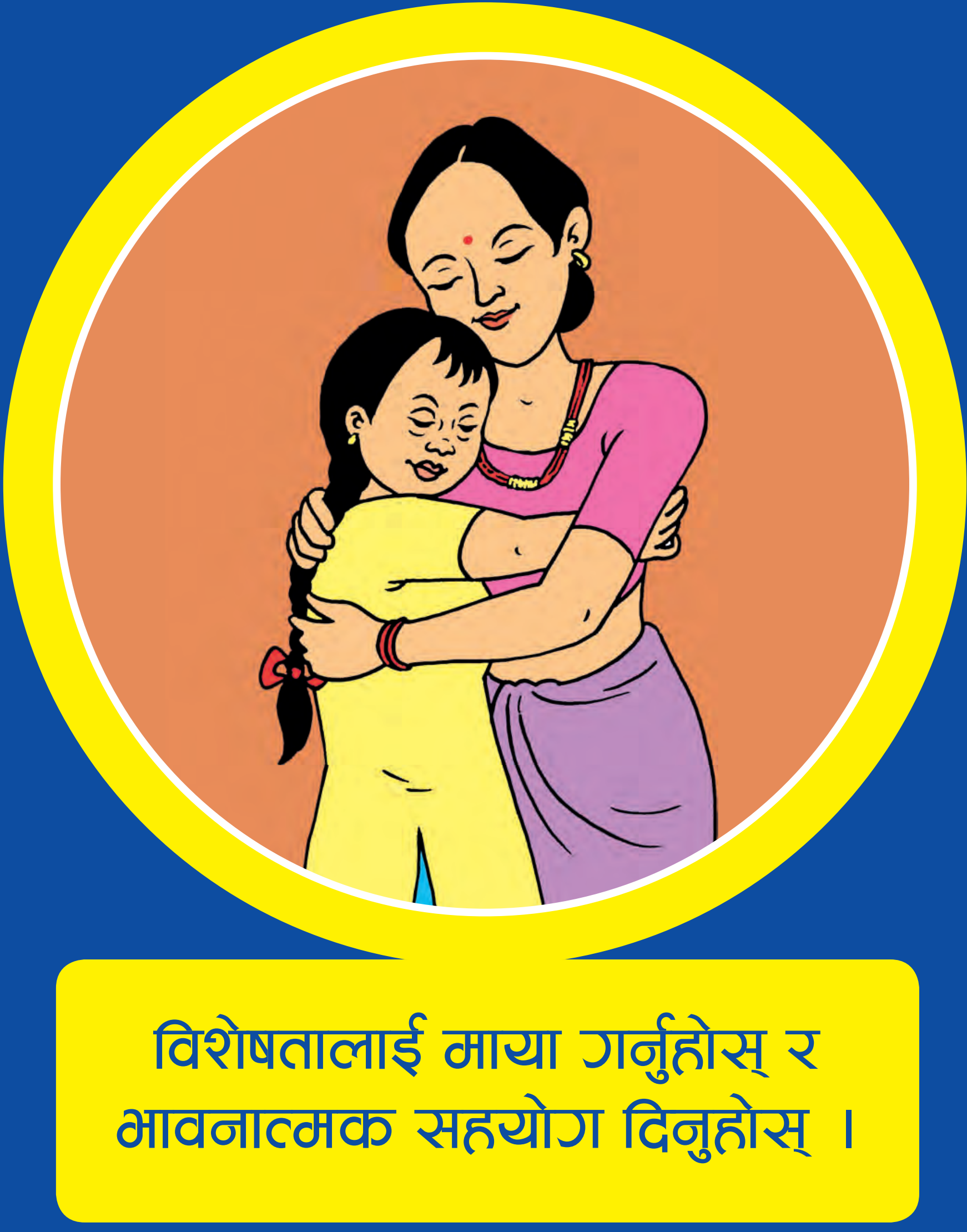




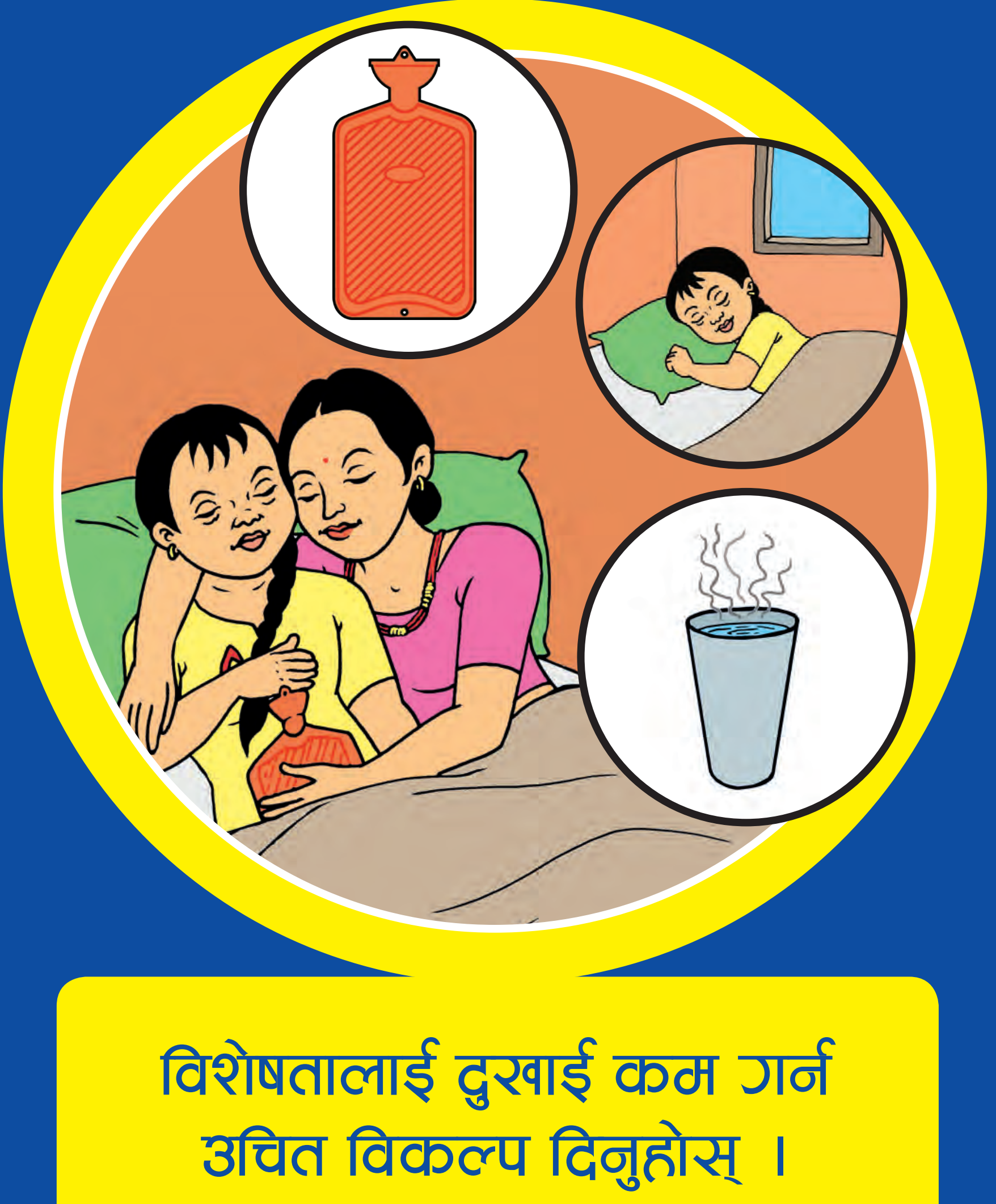




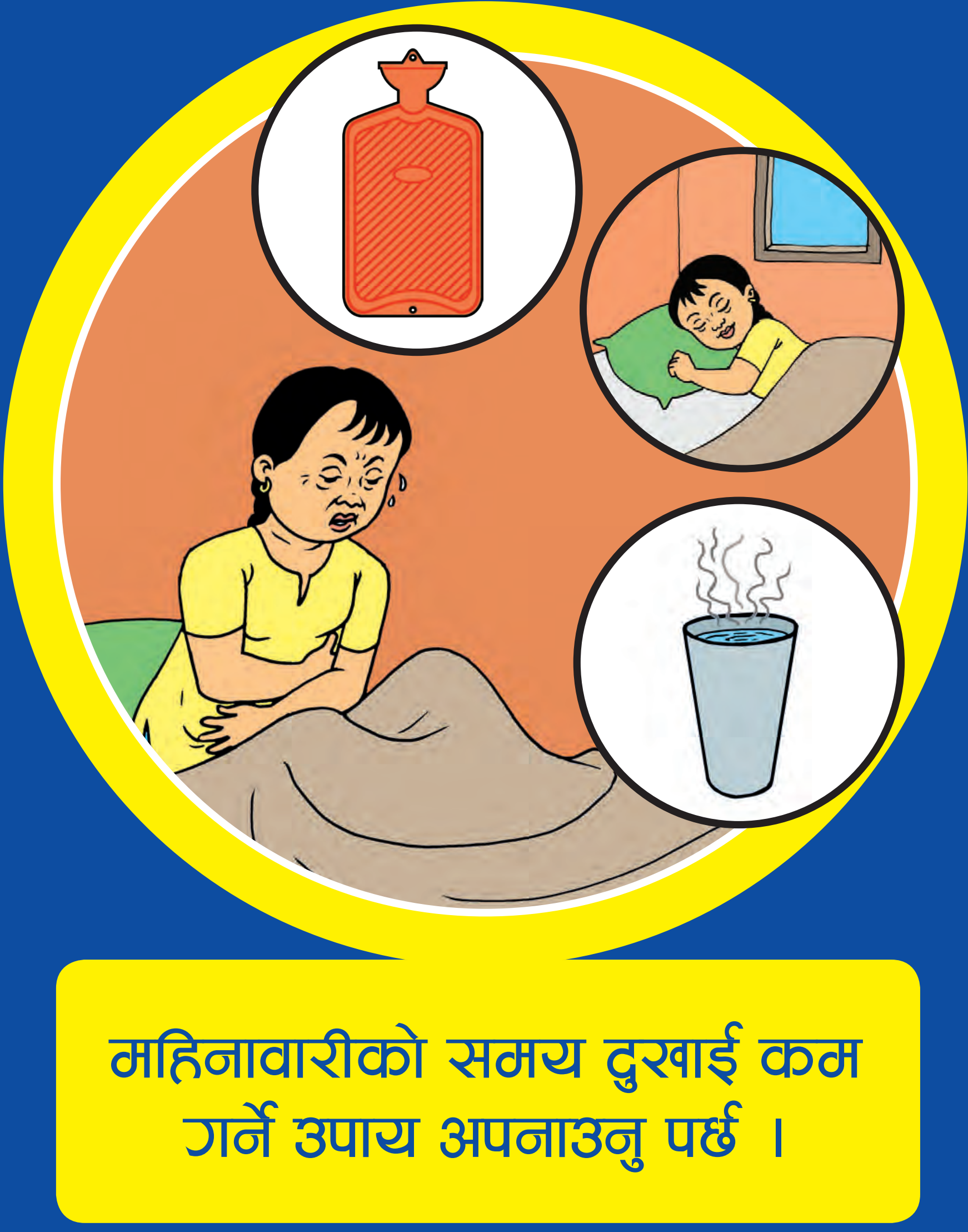




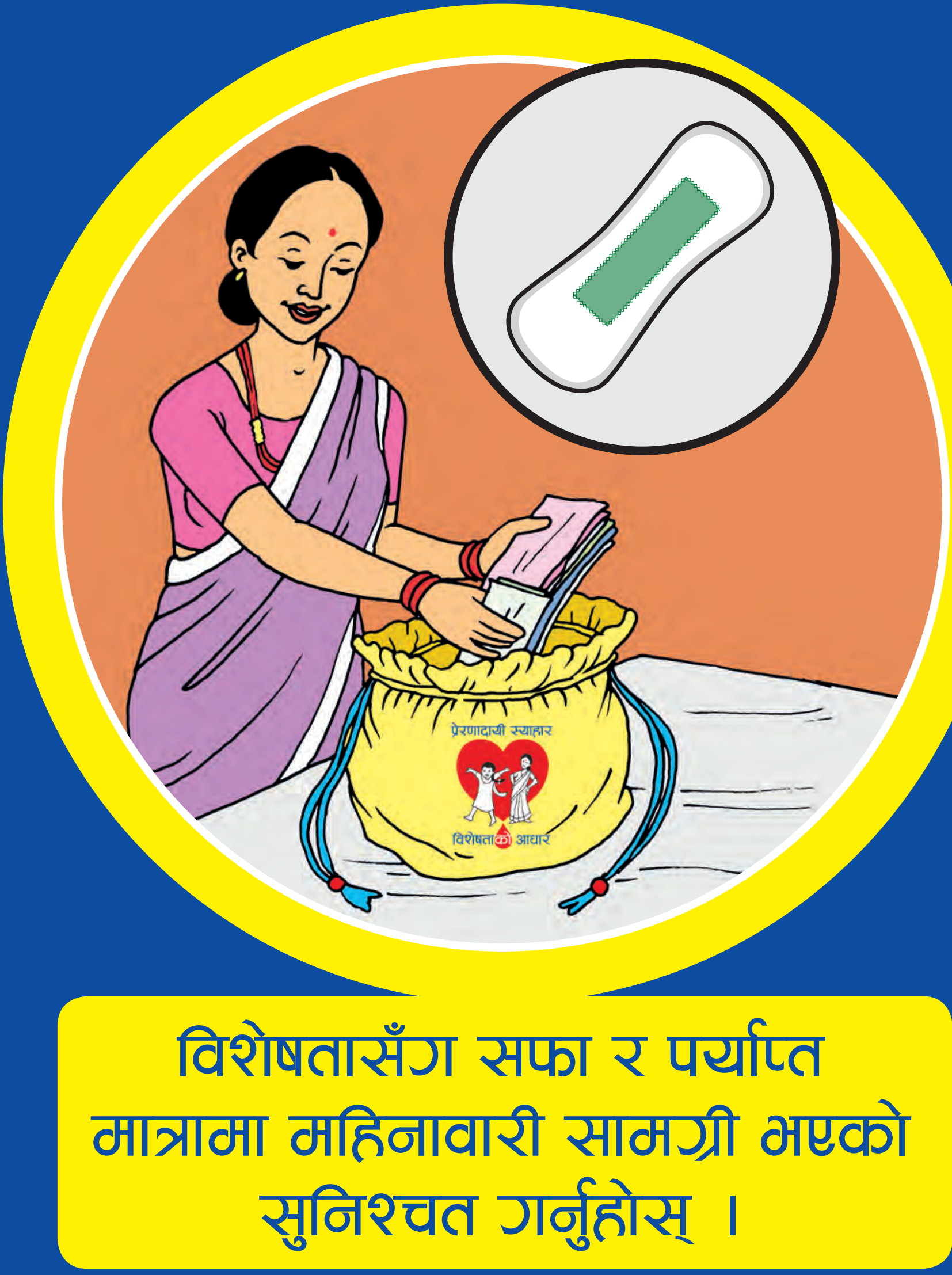




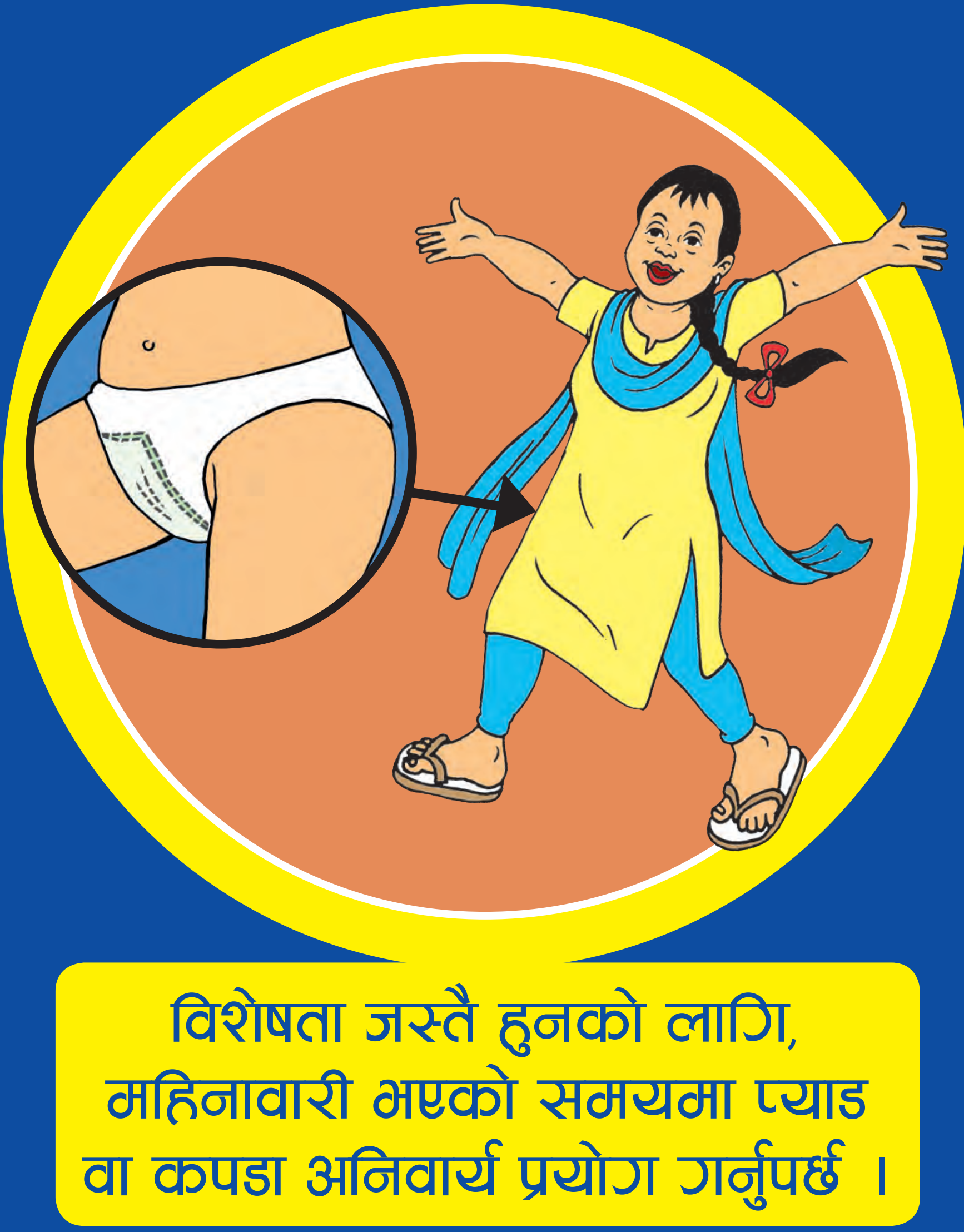


Jane Wilbur, Thérèse Mahon and Shila Thapa Illustrations by Raju Shakya (Sarab)

\section{I change my pad}

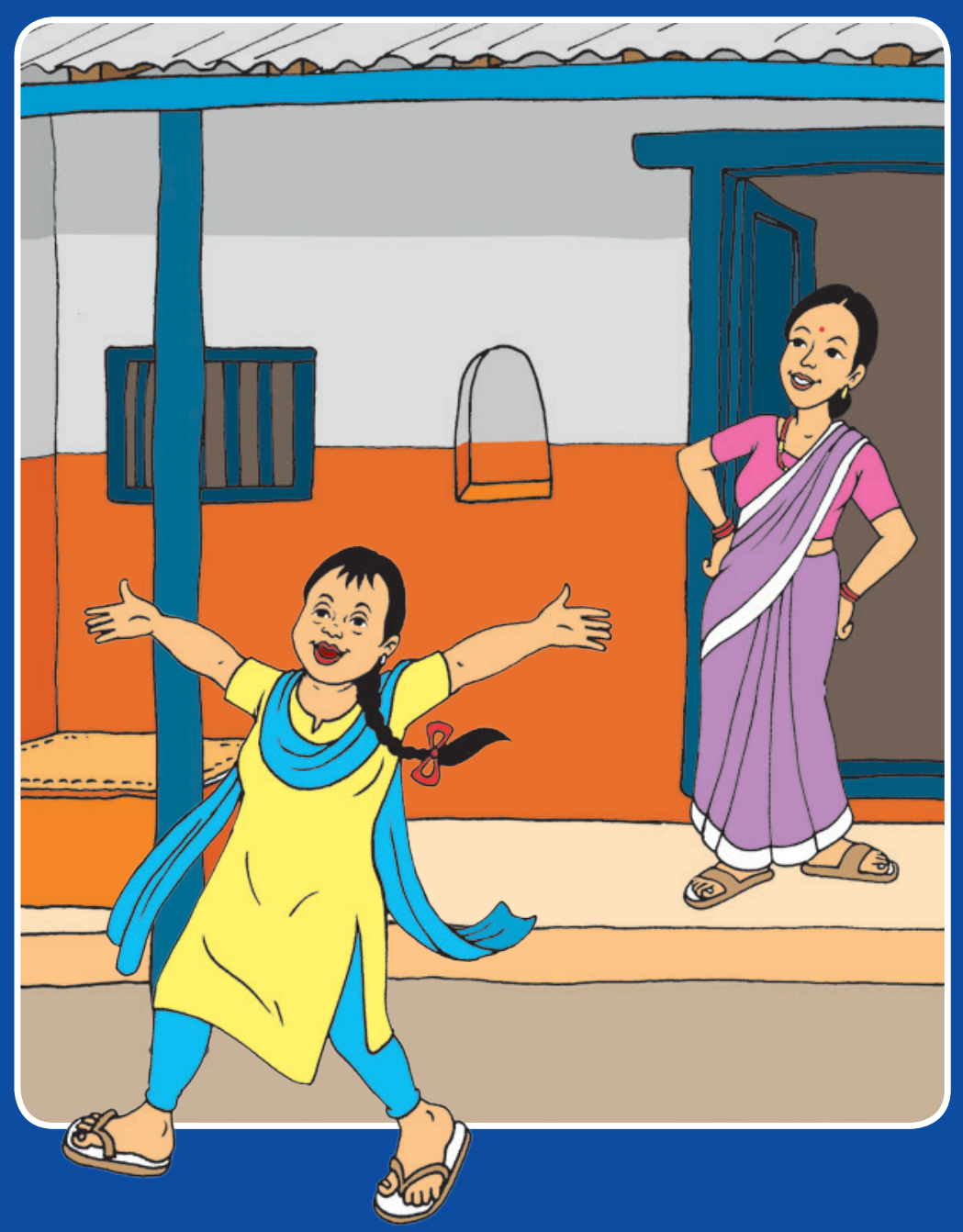

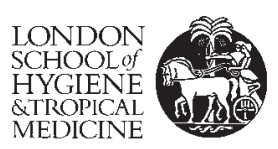

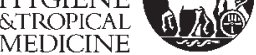

$224.144 .5810 .3362 / 17563489.21000042021091710: 0416$

\section{प्रेरणादायी स्याहार



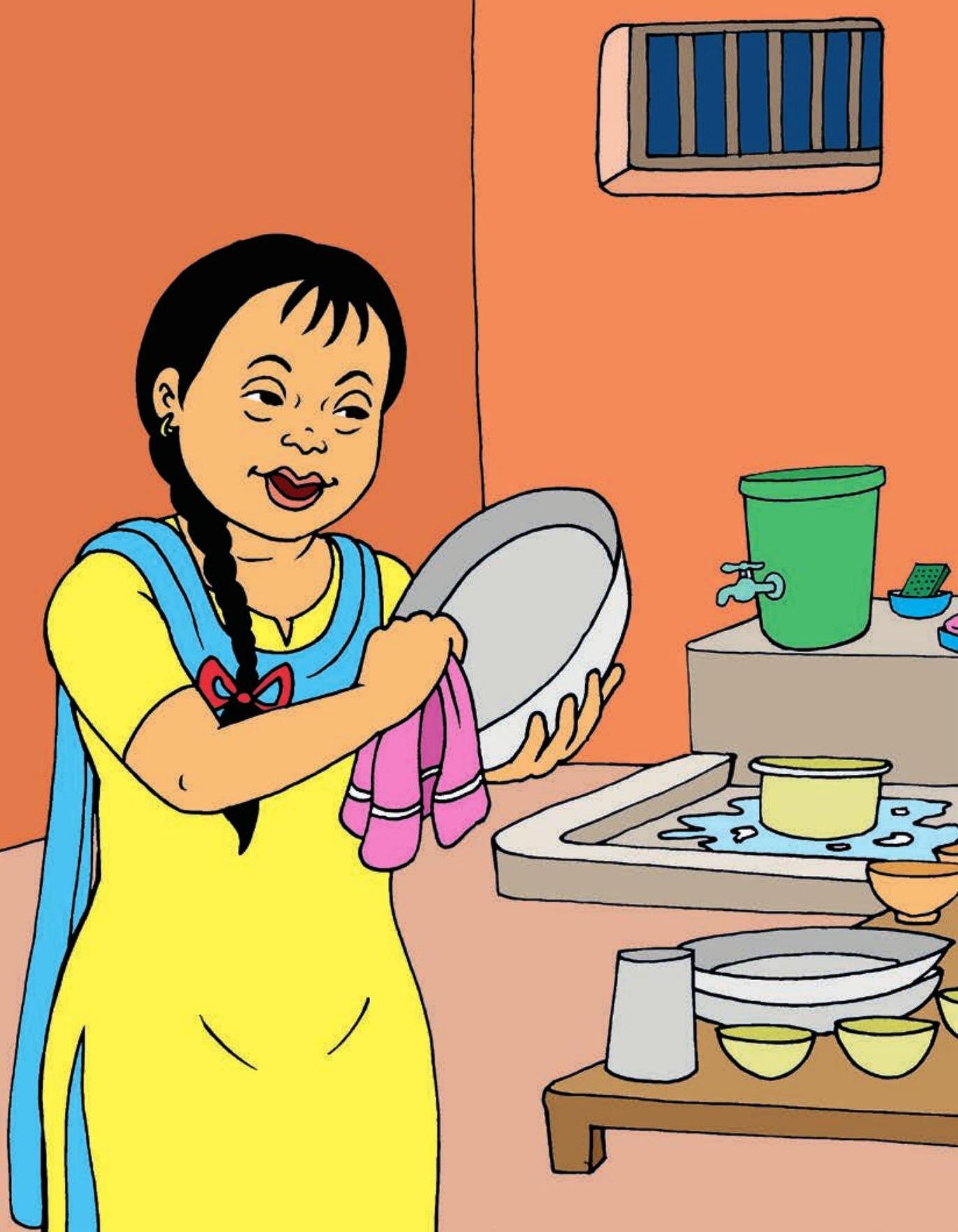


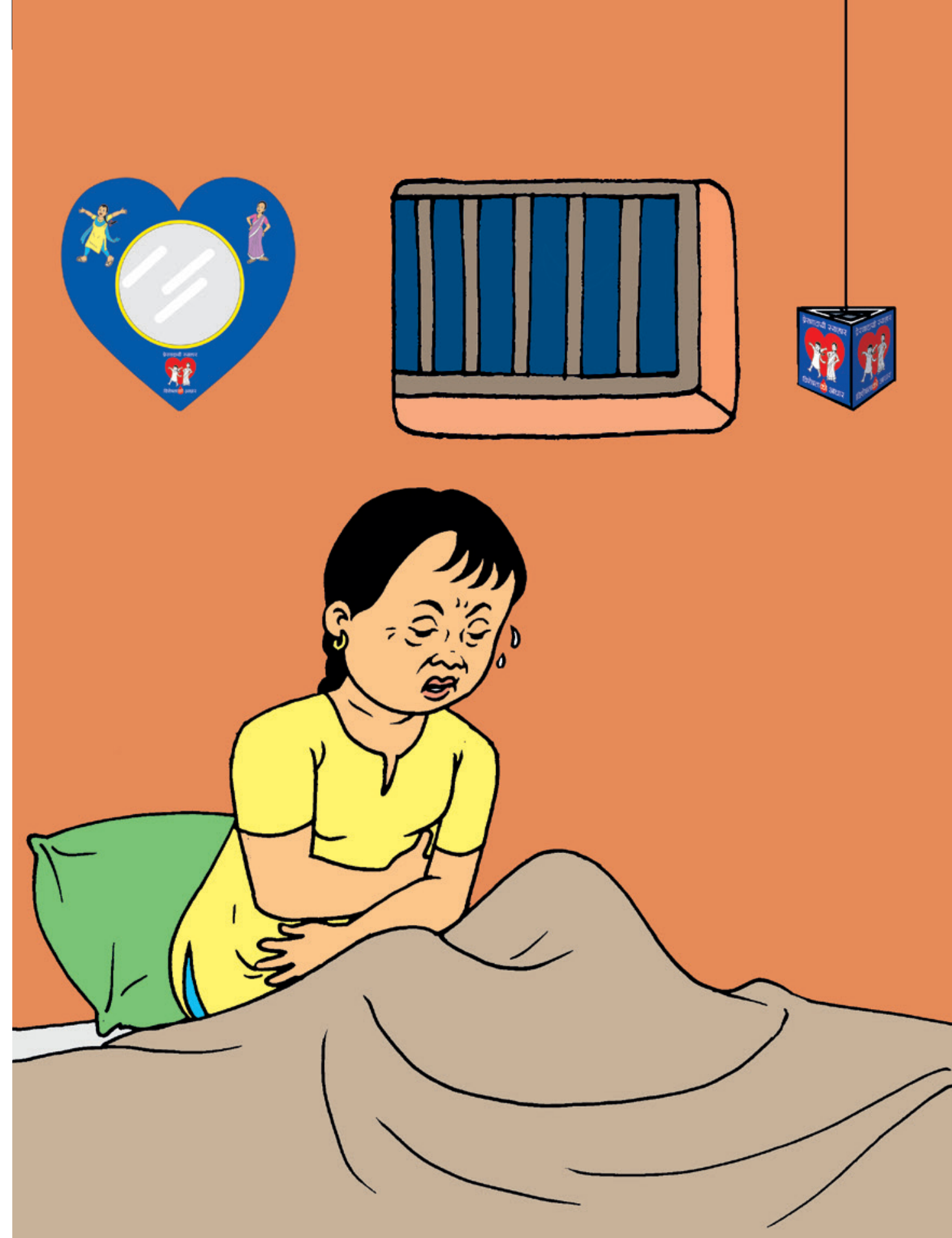




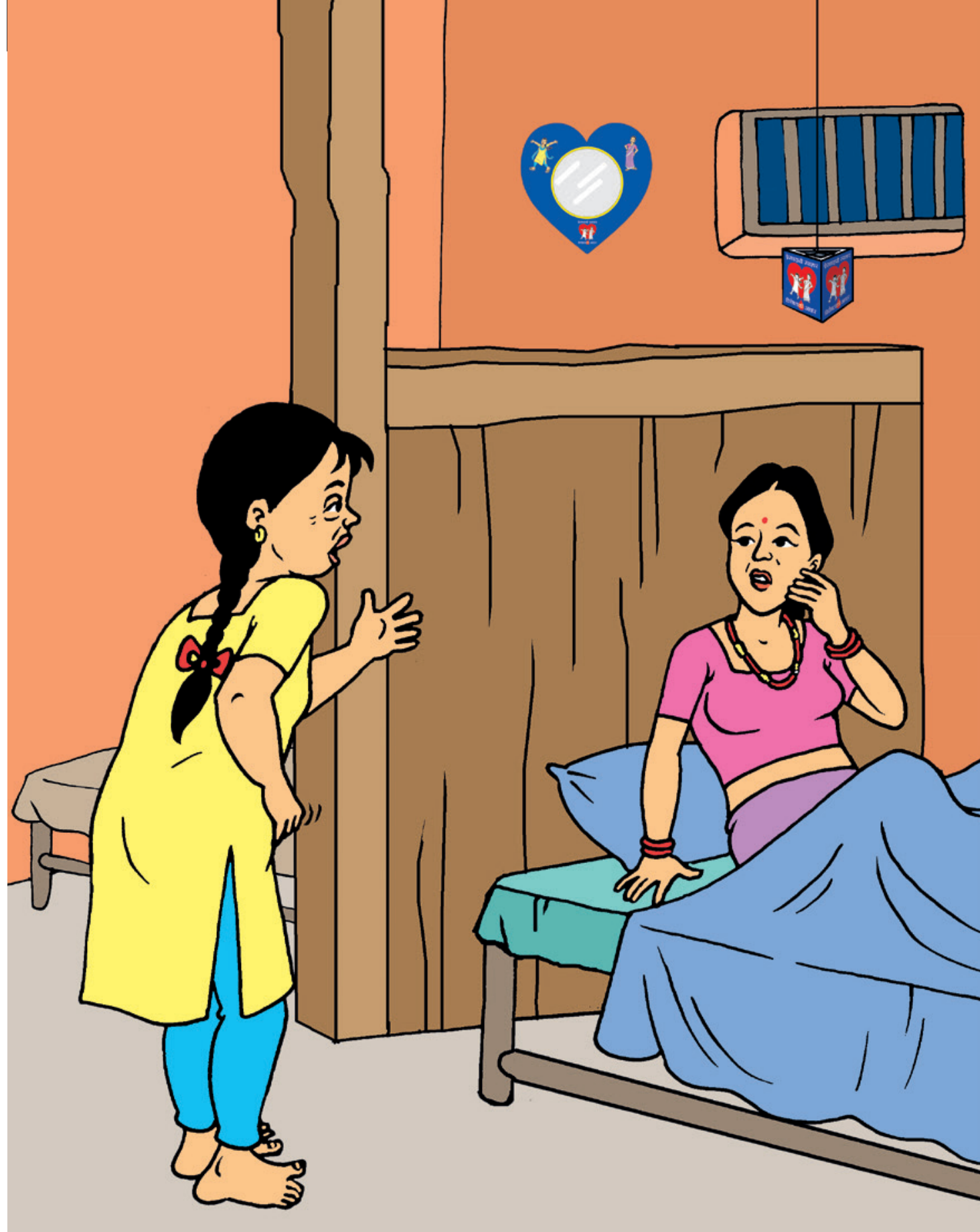




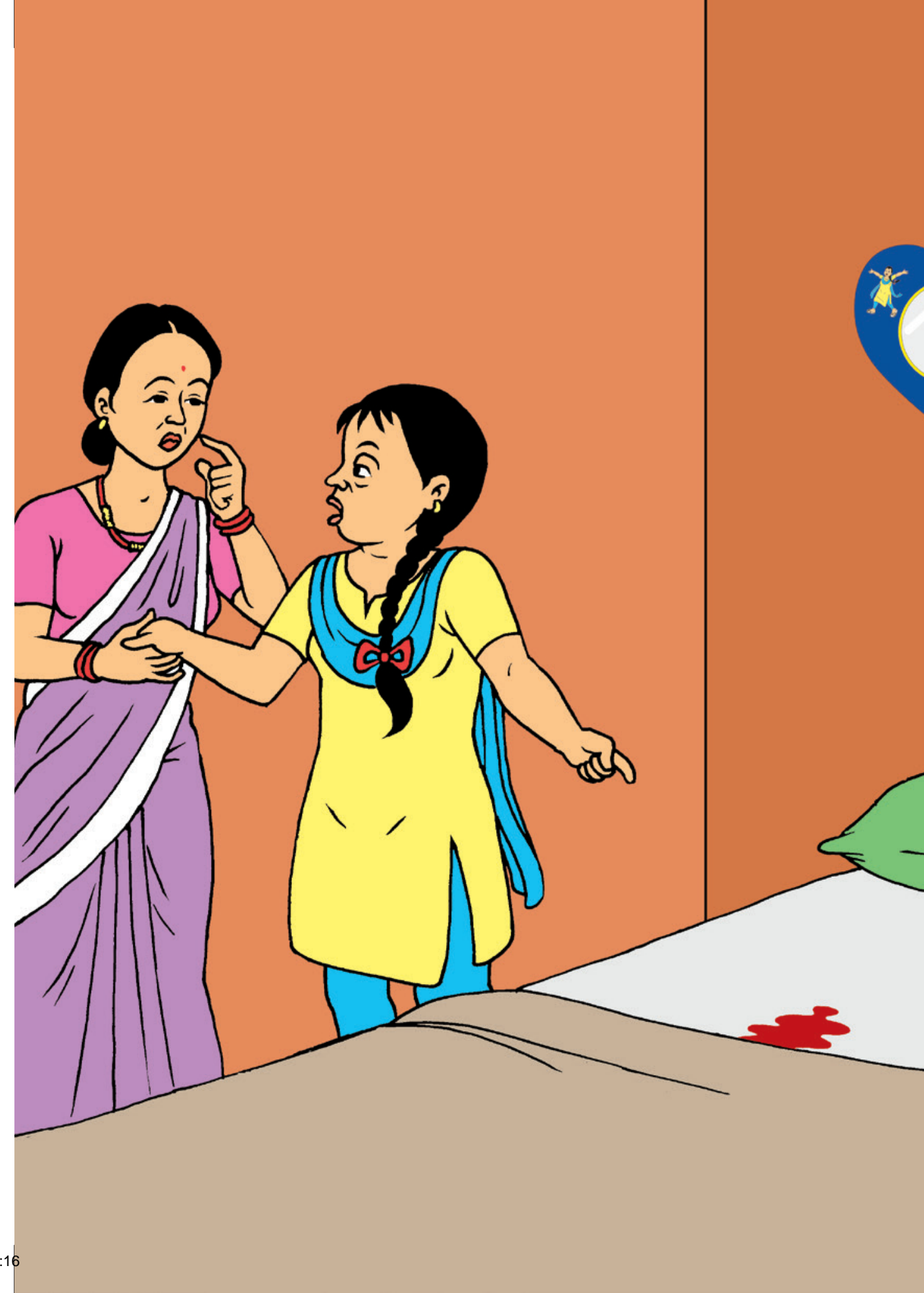



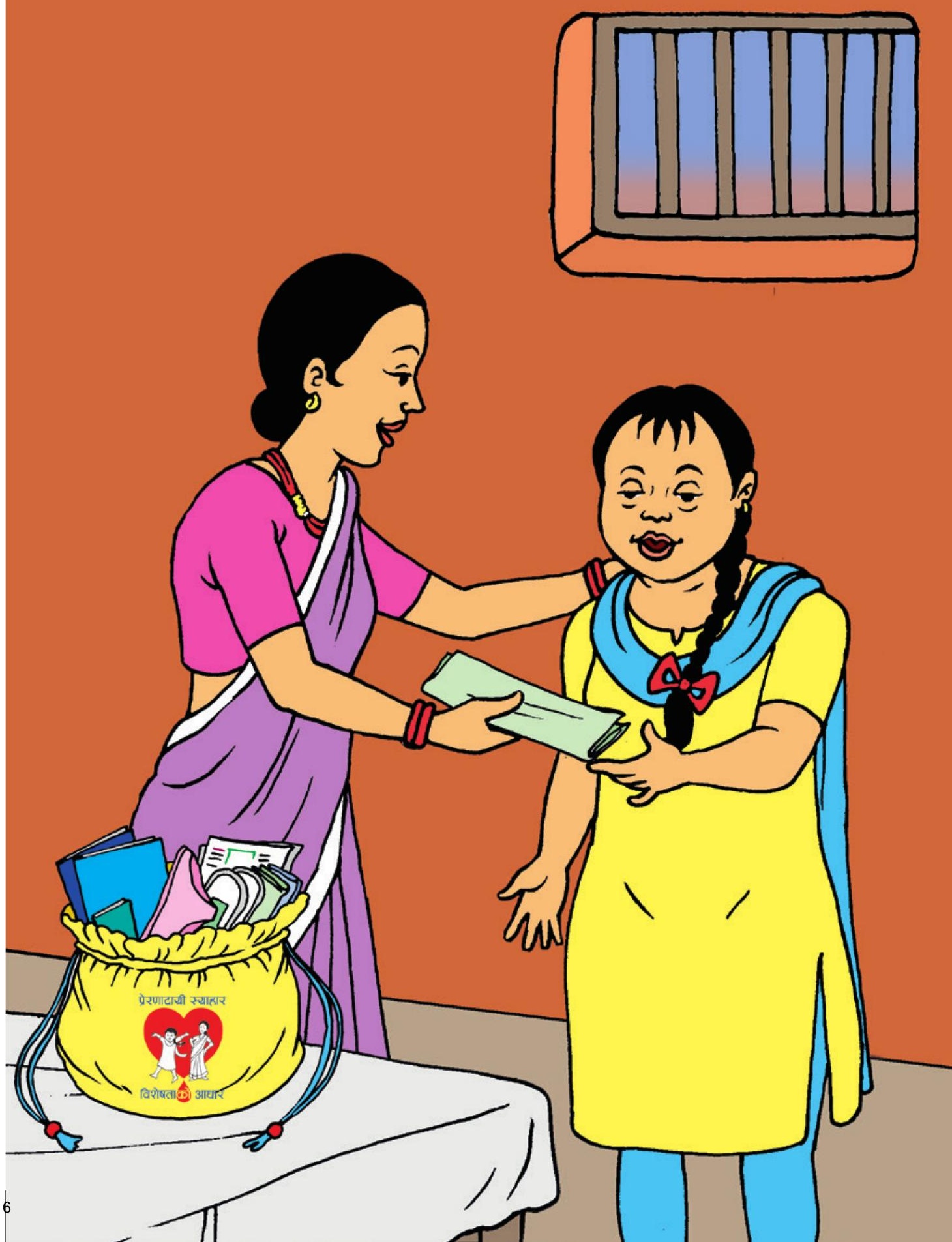


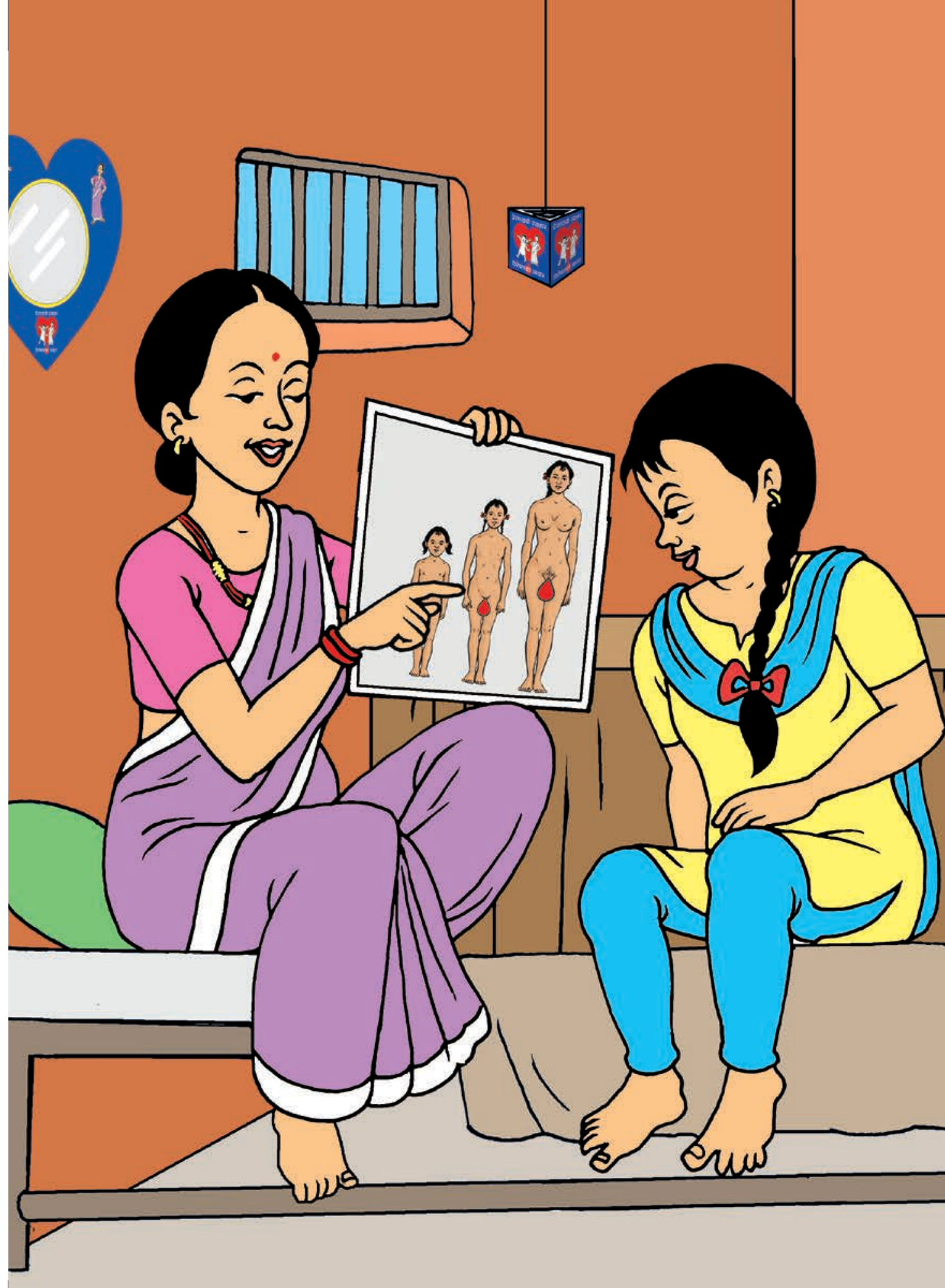




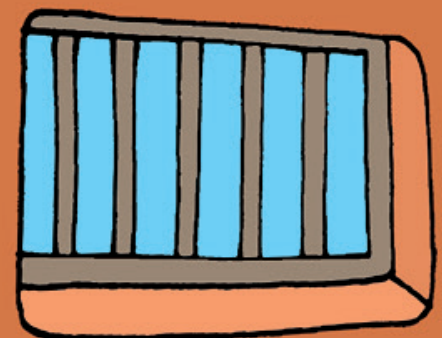

.
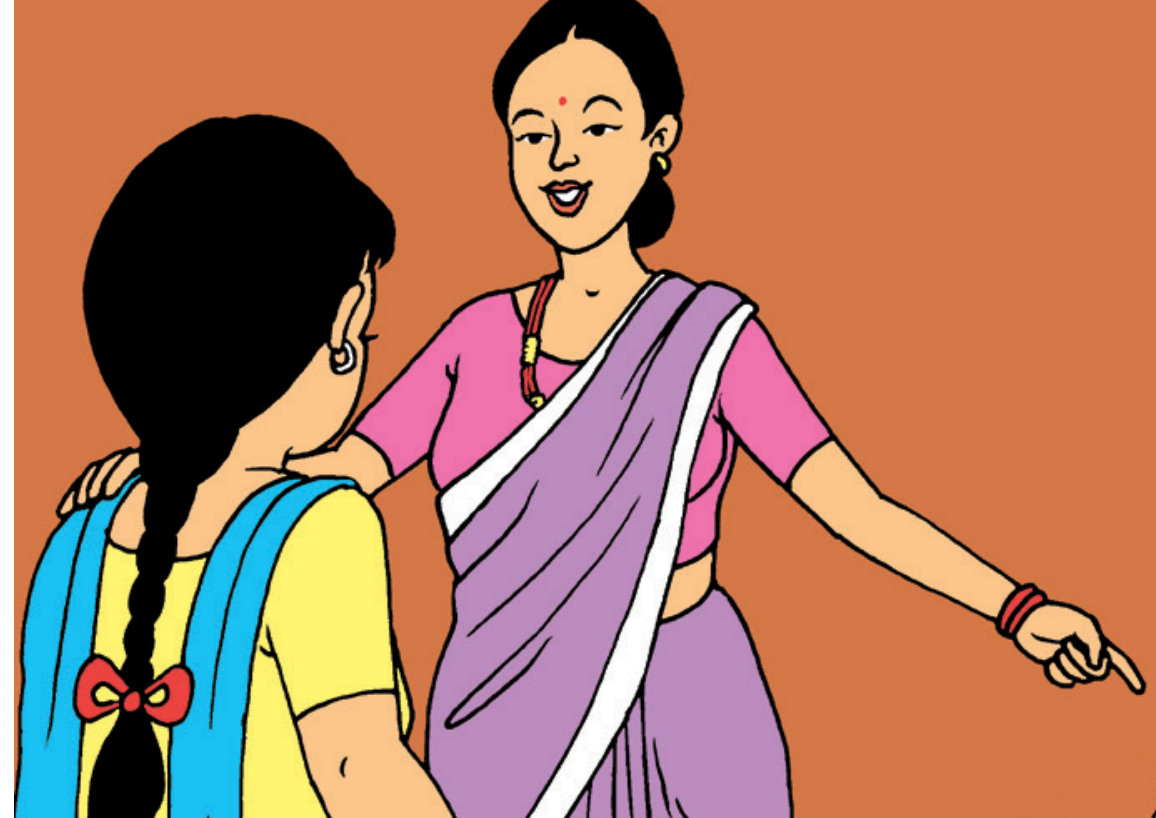


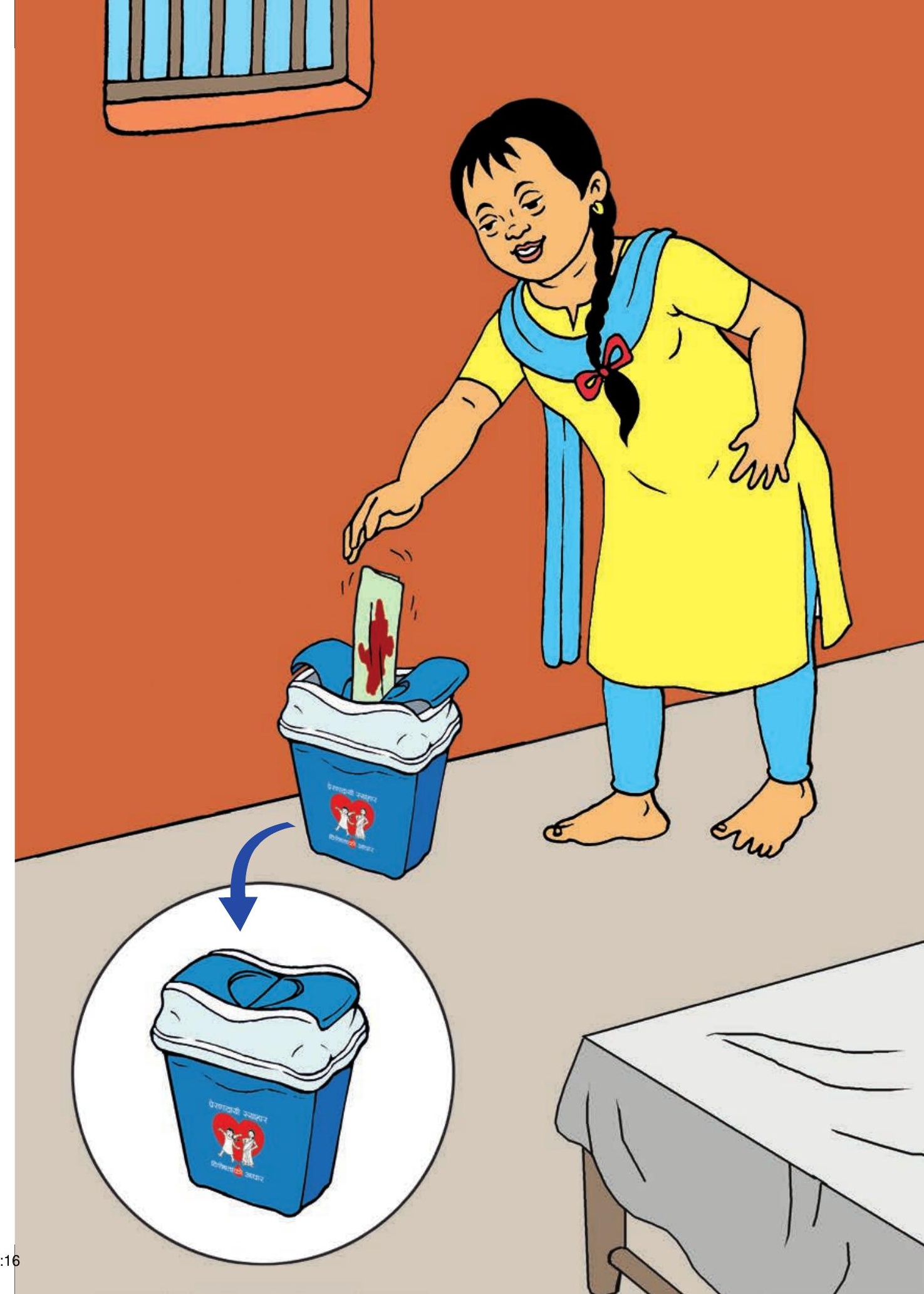




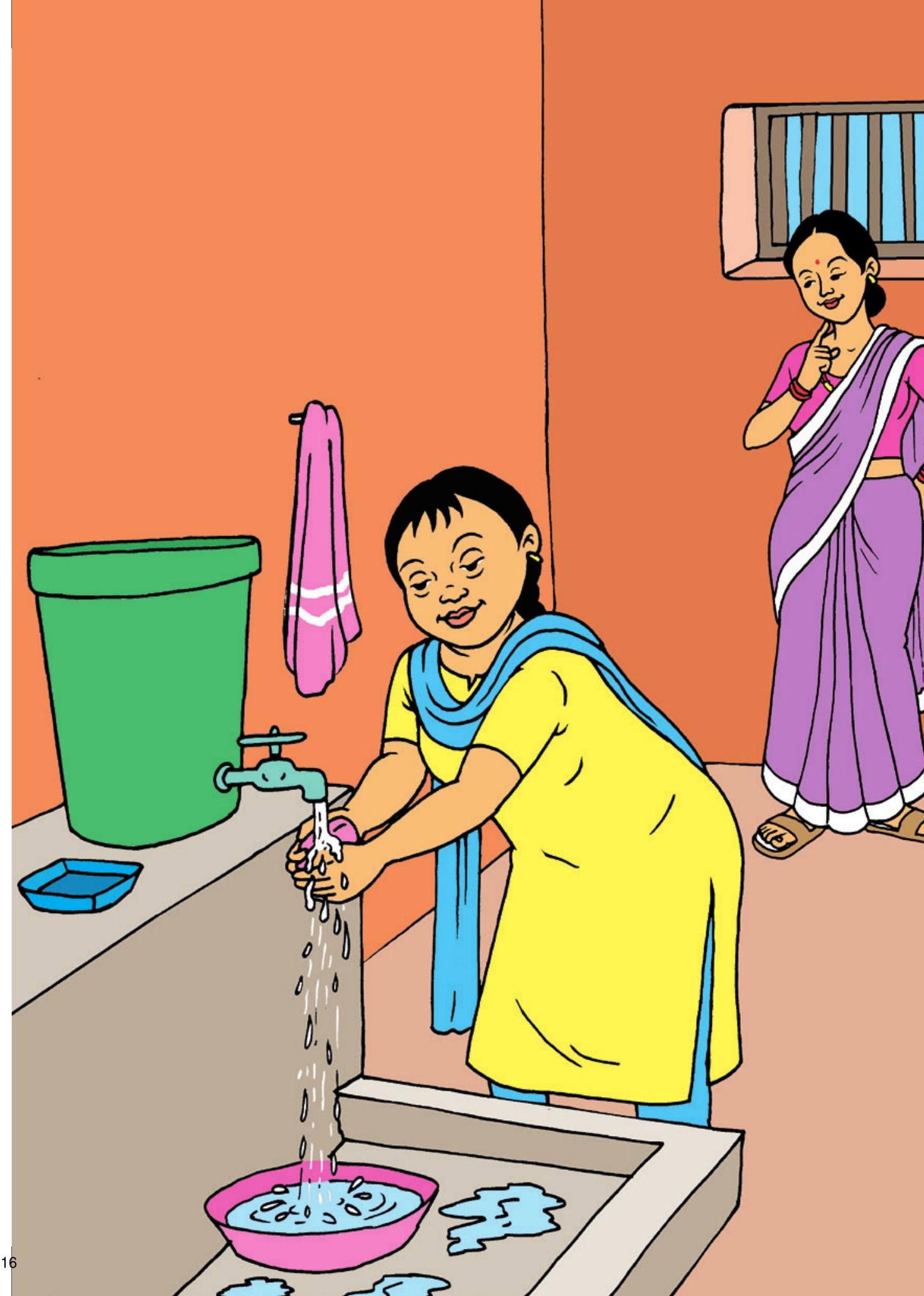




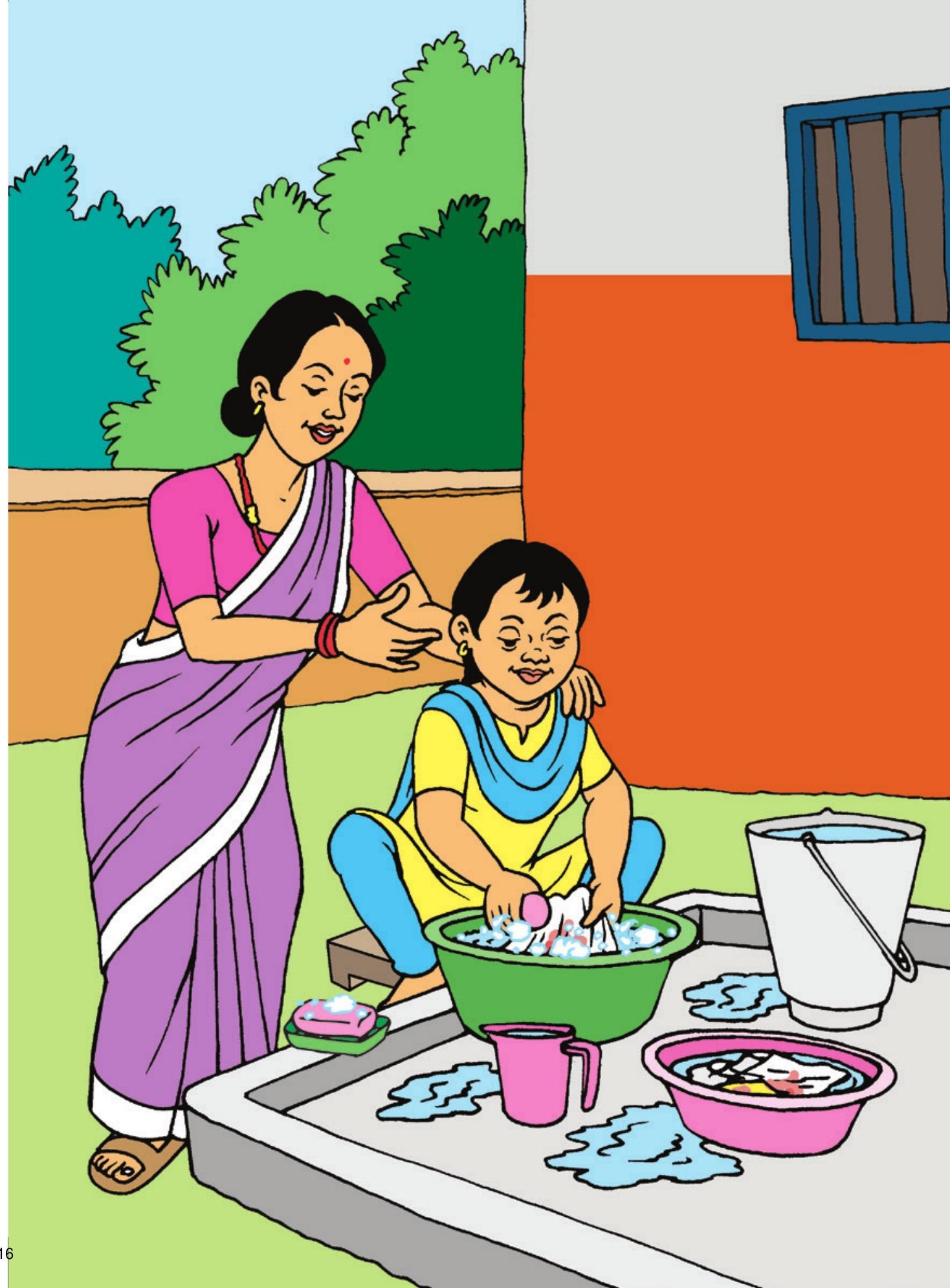



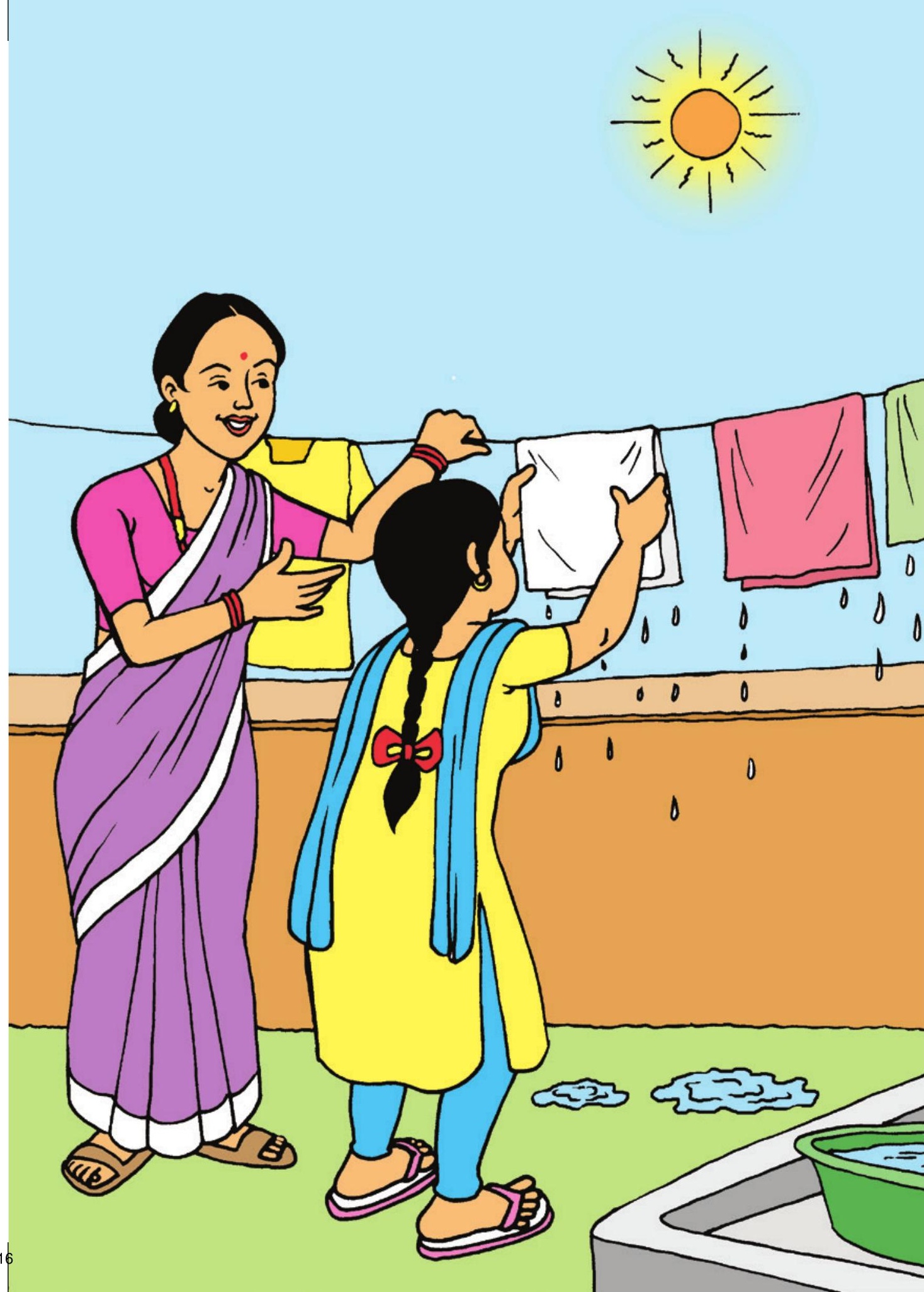


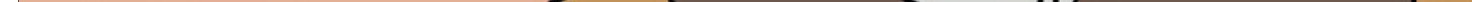




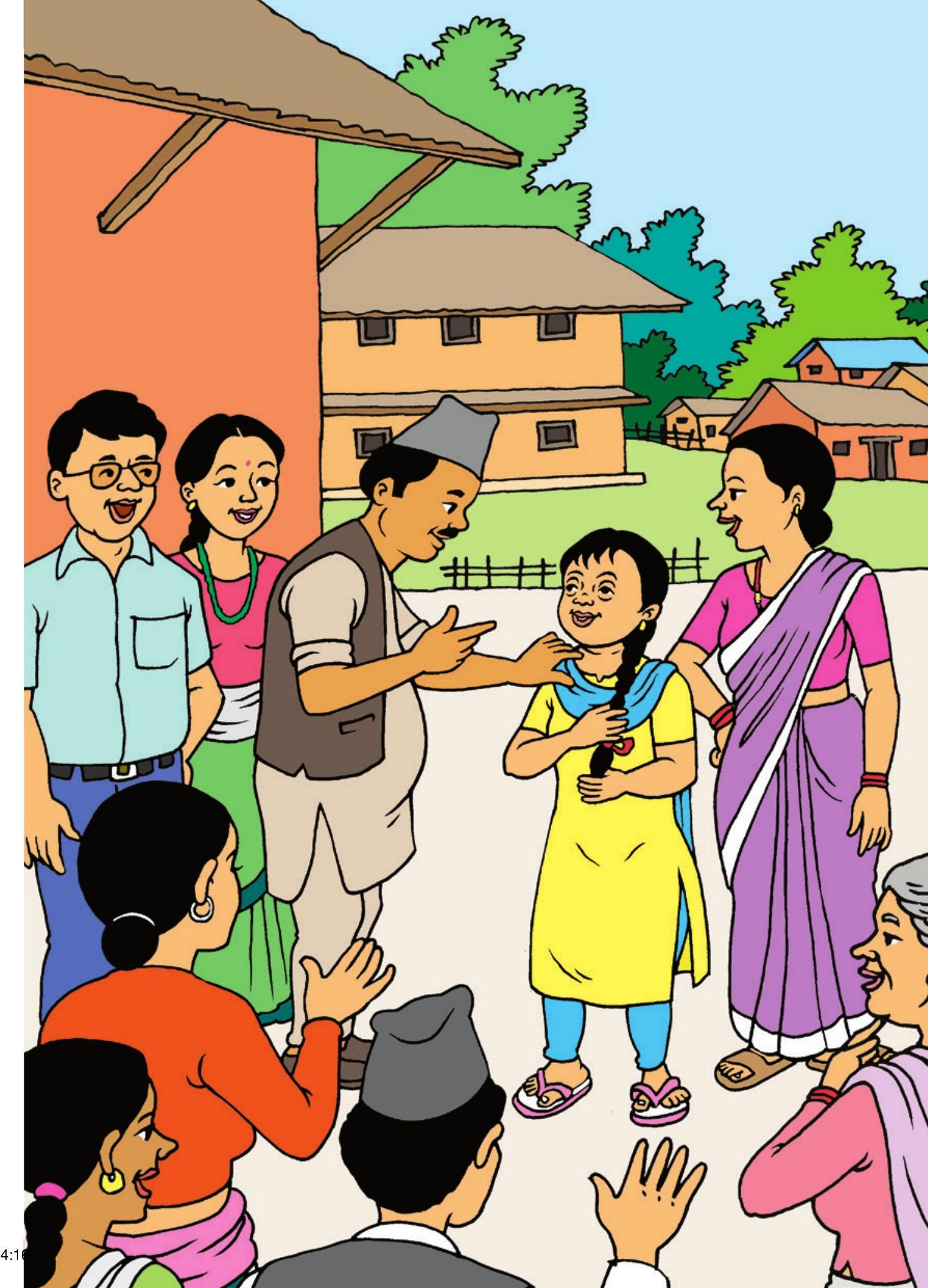




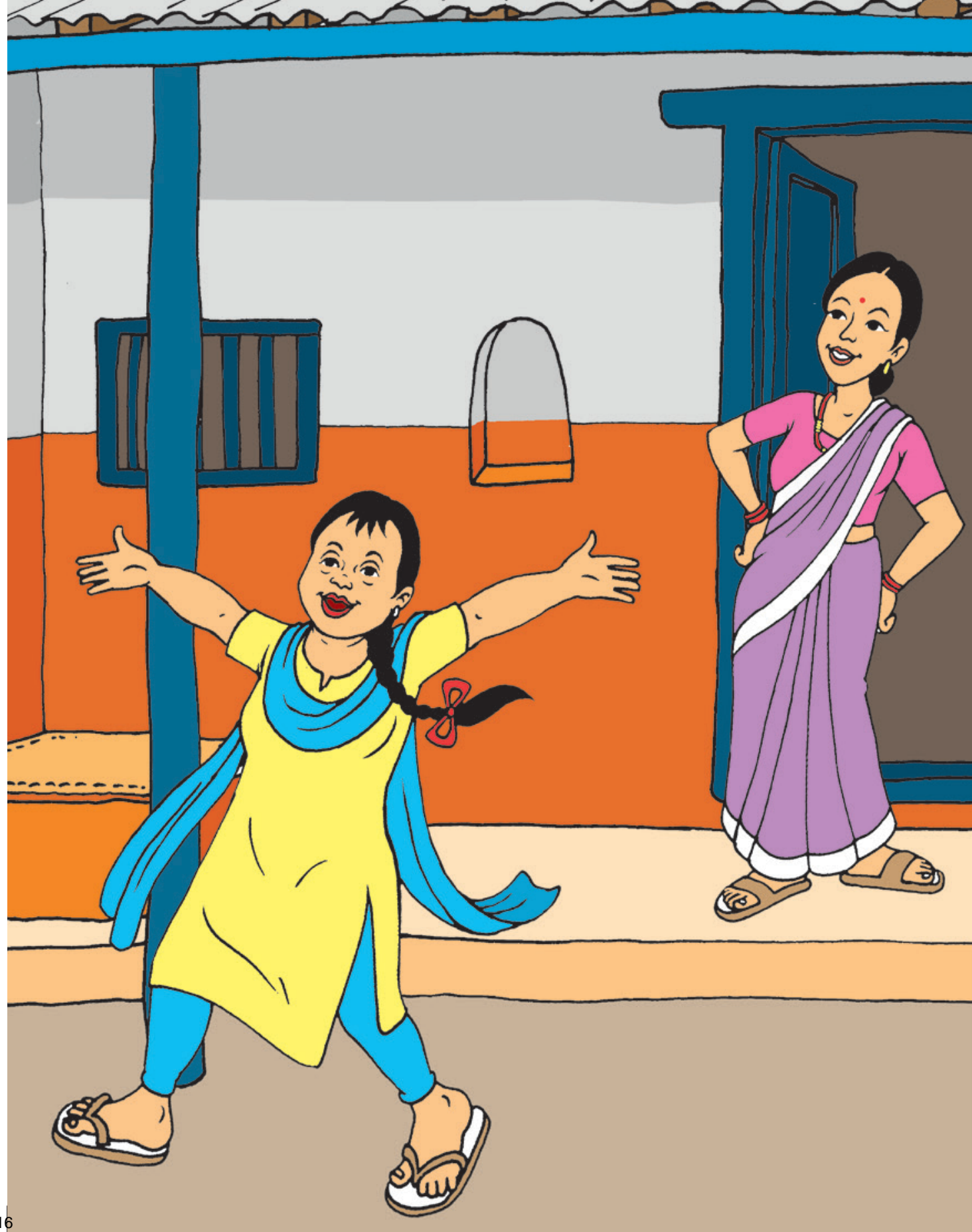




\section{The following words are for carers who want a ready- made story rather than making up your own.}

Page 1: Bishesta helps with the household chores.

Page 2: Bishesta refuses to eat because she has menstrual cramps.

Page 3: Bishesta has menstrual cramps.

Page 4: Bishesta goes to Perana for help.

Page 5: Perana comforts Bishesta.

Page 6: Perana gives Bishesta a hot water bag to put on her stomach. Perana comforts Bishesta.

Page 7: $\quad$ Bishesta gets up in the morning and sees blood on her bed.

Page 8: Bishesta goes to see Perana.

Page 9: Bishesta shows Perana the blood in her bed.

Page 10: Perana gives a clean menstrual cloth to Bishesta.

Page 11: Perana puts more menstrual cloths in the menstrual storage bag.

Page 12: Perana shows Bishesta how to put the menstrual cloth in her underwear.

Page 13: Perana explains to Bishesta that girls menstruate when they reach puberty. It is normal and there is nothing to be scared about.
Page 14: Perana shows Bishesta her menstrual storage bag and the menstrual shoulder bag.

Page 15: Perana shows Bishesta the menstrual bin.

Page 16: Bishesta puts her used menstrual cloth in the bin.

Page 17: Bishesta washes her hands with soap and water.

Page 18: Bishseta washes her used menstrual cloth. Perana guides her to do this.

Page 19: Bishesta hangs the washed menstrual pad in direct sunlight to dry. Perana guides her to do this.

Page 20: The Bishesta family sit and eat together.

Page 21: A group of people greet Bishesta and Perana.

Page 22: Bishesta is happy and comfortable. Perana is proud of Bishesta. 